\title{
Palaeoenvironmental and sea level changes during the Holocene in Eastern Saudi Arabia and their implications for Neolithic populations
}

\author{
Adrian G. Parker 1,2, Mike W. Morley3, Simon J. Armitage ${ }^{4,5}$, Max Engel6, Ash Parton 1,7, \\ Gareth W. Preston' ${ }^{1}$, Hannah Russ ${ }^{8}$ and Philipp Drechsler ${ }^{9}$
}

\author{
${ }^{1}$ Human Origins and Palaeoenvironments Research Group, School of Social Sciences, Oxford \\ Brookes University, Gipsy Lane, Oxford, OX3 0BP, United Kingdom \\ ${ }^{2}$ Australian Research Council (ARC), Centre of Excellence for Australian Biodiversity and \\ Heritage, University of Wollongong, Wollongong, New South Wales 2522, Australia \\ ${ }^{3}$ Department of Archaeology, College of Humanities, Arts \& Social Sciences, Flinders University \\ GPO Box 2100, Adelaide, SA 5001, Australia \\ ${ }^{4}$ Department of Geography, Royal Holloway, University of London, Egham, Surrey, TW20 0EX, \\ United Kingdom \\ ${ }^{5}$ Centre for Early Sapiens Behaviour (SapienCE), University of Bergen, Sydnesplassen 12/13, \\ Bergen, Norway \\ ${ }^{6}$ Institute of Geography, Heidelberg University, Im Neuenheimer Feld 348, 69120 Heidelberg \\ Germany \\ 7 Mansfield College, University of Oxford, Oxford, OX1 3TF, United Kingdom \\ ${ }^{8}$ Archaeology.biz, 39 Marwood Drive, Barnard Castle, County Durham, DL12 8DF, United \\ Kingdom \\ ${ }^{9}$ Institute of Pre- \& Protohistory and Medieval Archaeology, Early Prehistory and Quaternary \\ Ecology, Department of Geosciences, University of Tübingen, Tübingen, Germany
}

\begin{abstract}
This paper presents the key findings of a multidisciplinary study investigating the nature and timing of coastal landscape evolution in eastern Saudi Arabia during the Holocene. To date, most sea level reconstructions for the Arabo-Persian Gulf are based on uncalibrated ${ }^{14} \mathrm{C}$ ages without correction for marine reservoir effects, or lack precision with regard to the effects of neotectonic changes, indicators of sea level used, errors in elevation of sedimentary units used, and the relationship with actual tides. As a consequence, the nature and timing of relative sea level (RSL) changes during the Late Pleistocene and Holocene remain poorly understood. To help address this, we use sea level index points (SLIPs) based on calibrated ${ }^{14} \mathrm{C}$ ages to present a RSL curve for the central-southern Gulf of Saudi Arabia from coastal sabkha deposits near the archaeological site of Dosariyah. The
\end{abstract}


sediments record rapid transgression during the early Holocene with a midHolocene high-stand immediately prior to $6880-6560 \mathrm{cal}$. BP when the upper limit for the palaeo Mean Highest High tide water (MHHW) was 2.8-3.10 m above present day mean sea level. Transgression continued until shortly after 5575$5310 \mathrm{cal}$. BP with an upper limit to the palaeo-MHHW of $3.75 \mathrm{~m}$ above present sea levels. Thereafter a fall in RSL was recorded, with the regression leading to the progradation of the coastal system and the development of coastal sabkhas. Nonetheless later transgressions are recorded in the region between 4848-4536 and 4335-3949 cal BP. Radiometric dating results from archaeological excavations at Dosariyah, one of the most important Neolithic coastal sites in the Gulf, suggest that occupation of the site during the Neolithic coincides with the mid-Holocene marine transgression (ca. 7200 - 6500 cal. BP). Whilst the close proximity of the site to the sea may have facilitated maritime exchange activities, occupation of the site was short-lived and the phase of abandonment occurred during a period of rapid RSL rise, which would have transformed the area around Dosariyah into an island or certainly cut it off tidally from the mainland.

Keywords: Holocene; Sea level changes; Middle East; Sedimentology, lakes, lagoons \& swamps; Palaeoenvironments; Arabia; Neolithic; Dosariyah

Corresponding Author: Adrian Parker (agparker@brookes.ac.uk) 


\section{$1 \quad$ Introduction}

The Arabo-Persian Gulf (hereafter referred to as the Gulf) is a shallow epicontinental sea formed in the late Miocene by the collision of the Arabian and Eurasian plates. This produced the Zagros Fold Belt in Iran and the large Mesopotamian Foredeep, which is a member of the Gulf Basin (Purser, 1973; Lambeck, 1996; Teller et al., 2000). During the Quaternary, sea-level fluctuations with high-stands up to several metres above present levels to low stands of -120 m have occurred (Lambeck, 1996; Uchupi et al., 1999), driving widespread geomorphological changes. To date, however, the nature and timing of relative sea level (RSL) changes during the late Pleistocene and Holocene remain poorly understood. Lambeck (1996) suggested that a rise in sea level began around $14 \mathrm{ka} \mathrm{BP}$ and proceeded rapidly to near present levels shortly before $6 \mathrm{ka}$ BP. In addition, Teller et al. (2000) postulated that if sea levels flooded across the $1000 \mathrm{~km}$ length of the Gulf from the Straits of Hormuz to the Tigris-Euphrates delta between 13 and $6 \mathrm{ka}$, the average lateral rate of change would have been $140 \mathrm{~m}$ per year, with transgression reaching a maximum at about $6 \mathrm{ka}$ BP. It has also been suggested that sea level was between 2.0 and $2.5 \mathrm{~m}$ higher than at present in the central Gulf during the mid-Holocene (Felber et al., 1978; Engel and Brückner, 2014) and $3.5 \mathrm{~m}$ in the northern part of the Gulf (Lambeck, 1996). In Abu Dhabi, Lokier et al. (2015) state that during the mid-Holocene transgression, RSL was at least $20 \mathrm{~cm}$ higher than today at $\sim 7100-6900 \mathrm{cal} \mathrm{BP}$. Transgression, with rapid flooding and shallow subtidal deposition, took place between 6890-6570 cal BP and continued until 5290-4750 cal BP when a still stand phase occurred (Lokier et al., 2015).

The nature and timing of Holocene environmental change in the eastern coastal region of Saudi Arabia is poorly understood, with only a few detailed geoarchives published to date. In addition, while the geomorphological setting of the region has been described in detail (e.g. Barth 1998; 1999), a chronology for the development of this landscape is largely unknown. Lacustrine and wetland deposits from adjacent regions, such as the Al Sulb Plateau (Jado and Zötl, 1984), Al-Hasa (Larsen, 1983), Nafud As Sirr (Schulz and Whitney, 1986) and the 
southern playa of Bahrain (Doornkamp et al., 1980), record wetter conditions during the Early to mid-Holocene (ca. 9500-5800 cal. BP), however, no detailed physical, chemical or biological analyses have been conducted. With respect to the archaeology of the region, numerous investigations since the 1960s from the site of Dosariyah, near the town of Jubail in the Eastern Province of the Kingdom of Saudi Arabia (Fig. 1), have revealed that the site was a major coastal settlement from the beginning of the 5th millennium BCE (Drechsler, 2011, 2018). The spectrum of material culture discovered at the site shows affinities to the Arabian Middle Neolithic (sensu Drechsler, 2007; 2009; 2011; Charpentier, 2008), with indications of intense cultural contacts with southern Mesopotamia. The 5th millennium BCE represents a flourishing period in prehistoric Arabia, with high numbers of archaeological sites suggesting a rapid growth of human populations, potentially enabled by wetter climatic conditions and increased resource availability (Parker and Goudie, 2008).

Despite these findings, no studies have thus far attempted to utilise a multidisciplinary approach for understanding the changing coastal landscape of the region during the Early to mid-Holocene. To address these issues, we present the first integrated study that explores the nature and timing of palaeoenvironmental, geomorphological and relative sea level (RSL) changes, and the potential impacts upon Neolithic populations within the region, based on findings from the archaeological site of Dosariyah. 


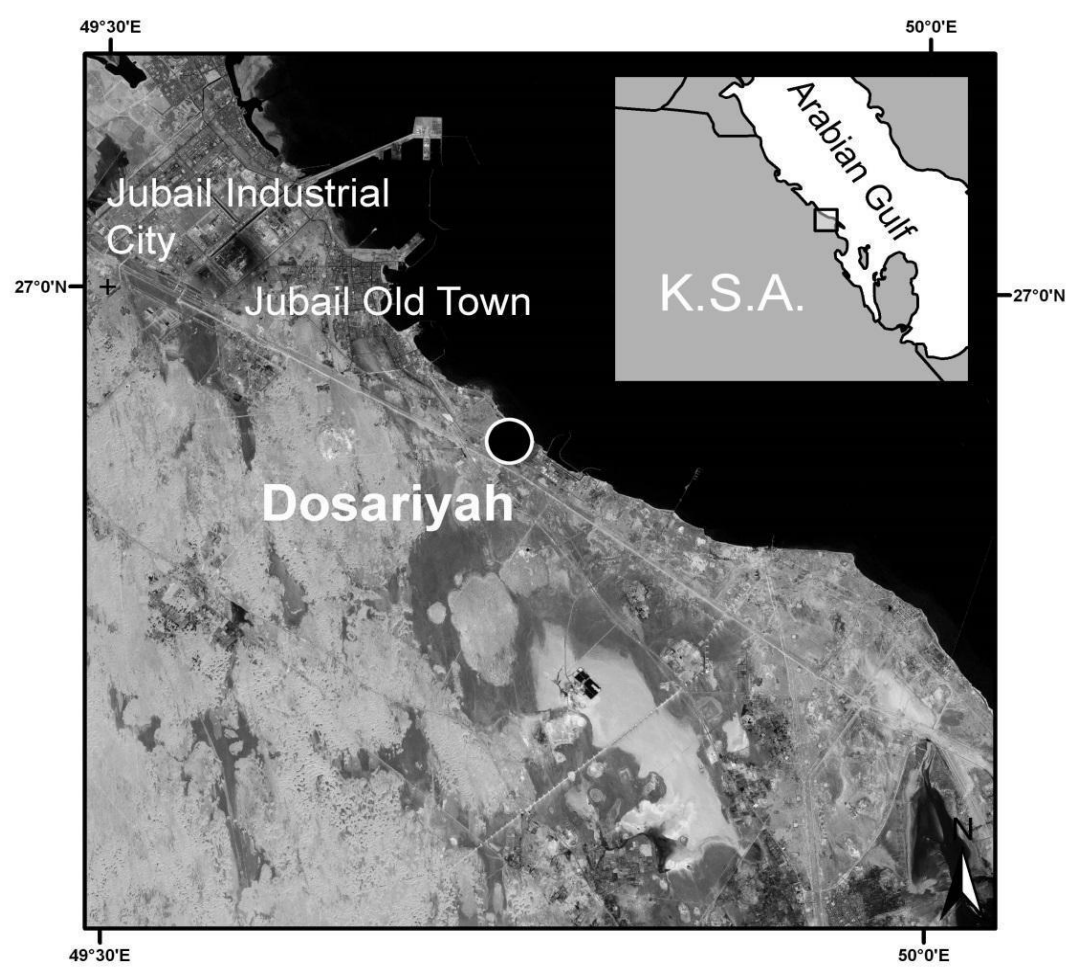

Figure 1: Location of Dosariyah, south of the Old Town of Jubail, KSA

(Drechsler, 2018).

\section{Background}

\subsection{Physical setting}

Dosariyah is located in the central coastal lowlands of the Eastern Province of Saudi Arabia close to the city of Al Jubail. The region has a desert and semidesert climate, characterized by high summer temperatures and aridity throughout the year. The mean annual temperatures recorded from the region are $26.5^{\circ} \mathrm{C}$ with July and December averages $35.8^{\circ} \mathrm{C}$ and $15.8^{\circ} \mathrm{C}$ respectively (Barth, 2001). Extreme temperature values range between $49.2^{\circ} \mathrm{C}$ and $4.1^{\circ} \mathrm{C}$. The average annual rainfall for the region is $85 \mathrm{~mm}$ with high inter annual variability (Drechsler, 2018). Predominant sources of rainfall are Mediterranean depressions during winter and spring supplemented by local convection cells that develop in front of the Zagros Mountains above Iraq and eastern Iran and currents from equatorial areas in Sudan and Ethiopia (Barth and Steinkohl, 2004). Evaporation rates exceed precipitation resulting in a high water deficit for the region. Strong shamal winds affect the region during the summer months with speeds up to $40 / 50 \mathrm{~km} / \mathrm{hr}$, while northwesterlies originating from 
depressions in the Mediterranean occur from November to February. The prevalent wind direction is from the north and northwest and are primarily responsible for the movement of sand across the central Gulf region (Barth, 2002).

This region, which stretches between As Saffaniyah in the north to Dharan in the south, is characterized by low relief Quaternary dune and sabkha depostis. A number of minor outcrops of Miocene bedrock belonging to the Hadrukh and Dam Formations are exposed as minor escarpments, buttes and mesas (5-20 m high). The Hadrukh Fm comprises very fine-to-medium grained siliciclastic sands, sandy gypsites, gypsiferous sands, brecciated lacustrine sandy carbonates and palaeosols (Alkhaldi et al, 2020) and underlies the whole of the Jubail area. A major Hadrukh Fm outlier, Jebel Barri, lies 9 km northeast of Dosariyah. Here in the limestone of the Hadrukh Fm chert and gypsum layers and prominent. Occasional small outcrops can also be found to the west of Dosariyah. Bedrock outcrops north of Jubail belong to the Dam Fm and comprise limestone, sandstone, marl and shale (Alkhaldi et al., 2020). Within the southeastern coastal area wind faceted yardangs are common features of the landscape, which are often found on low-lying outcrops and ridges of the Rus, Dammam and Hofuf Formations as well as being well developed in Quaternary carbonate aeolianite formations.

To the west lies the north-south trending As Summan Plateau, which ranges in height between $400 \mathrm{~m}$ and $150 \mathrm{~m}$ asl. Along the eastern flank of the plateau is a prominent escarpment incised by a number of wadis. The bedrock comprises sandy limestone of the Miocene Hofuf Formation (Nasir et al., 2007). The sparsely vegetated plateau is relatively flat with numerous sinkholes, solution cavities and caves.

The landscape around Dosariyah is characterized by a narrow coastal strip, dunes, interdune areas, sand sheets and siliciclastic sabkha terrains (Fryberger et al. 1984; Parker et al., 2018) (Fig. 2). Dosariyah itself is located on a raised area comprised of Quaternary Dammam aeolianites. These are dominated by 
well-sorted, fine to medium sands, and carbonate material comprising mostly ooliths, rounded skeletal fragments (coral, shell debris) and peloids, cemented by calcite, aragonite and gypsum (Hussain, 2006). At Dosariyah outcrops are exposed at the surface along the coastal strip where they form a resistant cap, which in places has been faceted by wind action to form yardangs or is covered by younger dunes. These fossilised dunes break off rather steeply towards the sea, but are increasingly covered by sand sheets further inland. Both Pleistocene deflated longitudinal dunes and smaller Holocene dunes overlay the aeolianites. They are most conspicuous on the north-northwest/south-southeast trended deflated linear dune closest to the coast. Here, they top the summits of the high ground and are draped over the aeolianite surface on the landward side. In places these dunes are up to $3 \mathrm{~m}$ above the aeolianite surface and are whitish in color, having largely been reworked from the Dammam Formation. Over wide areas, scattered perennial grasses and herbs cover these dunes.

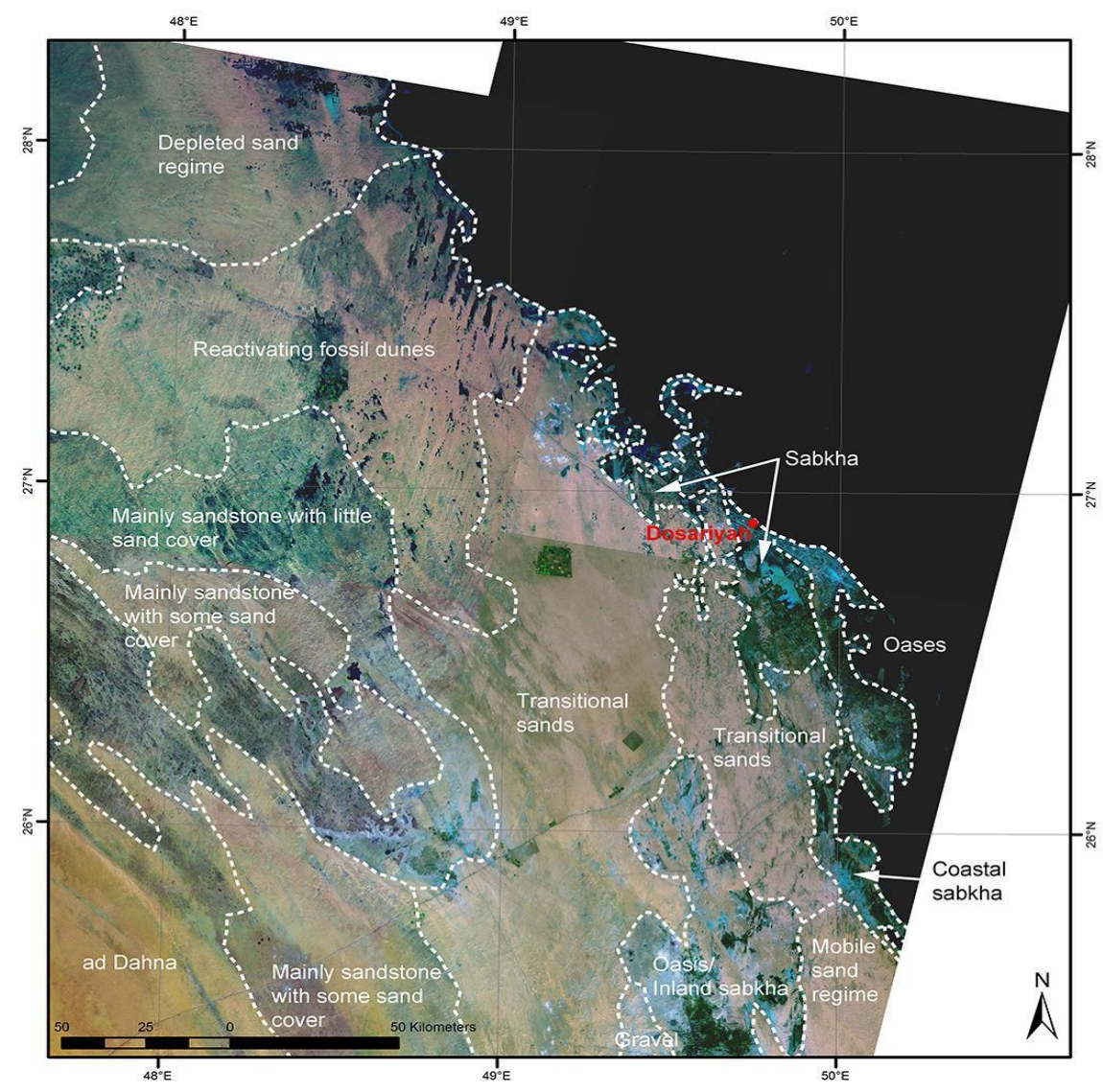

Figure 2: General geomorphological configuration of the central coastal lowlands. Dosariyah is located within a zone dominated by sabkhas (modified after Loughland et al., 2012:196). 
The landscape to the west, east and south of Dosariyah is dominated by wide sabkha flats of the Sabkhat as Summ, which constitutes one northern part of the larger Sabkhat ar-Riyas (Edgell, 2006) (Fig. 3). These sabkha flats form a wide arc around the raised area where Dosariyah is located. Shells from the marine snail Cerithium scabridum, which can be found on the surface of these sabkhas, indicate that they once were flooded during times of higher sea levels. A series of both active and inactive sand spits along the coast suggest that the sabkhas were connected to the open sea during the past. While clearly of marine origin, the surface morphology and height of the sabkhas is at least partly controlled by the local groundwater level (Barth, 1998). Strips of wind-blown sand cover part of the sabkha surfaces to the southeast of the raised area. They are both indicative for current sand transport induced by winds from the north-northwest and a comparatively older date of the sabkha itself. South and west of the Sabkhat as Summ, extensive dune fields are interrupted by smaller sabkhas (Sabkhat al Fasl, Sabkhat as Safi, Sabkhat Mahbulah) and hard rock outcrops (Jabal Barri, Jabal Abu Sharif) (Defense Mapping Agency, 1982). Along the western borders of Sabkhat as Summ and Sabkhat al Fasl, extensive palm groves exist that are no longer under cultivation, but indicate near-surface occurrences of fresh water. Across much of the desert interior, to the northwest and west of the site, active transverse barchanoid dunes occur. These dunes move at rates of up to $3 \mathrm{~m} / \mathrm{yr}$, driven by the Shamal winds (Barth, 2002). Overgrazing in more recent times has reduced the vegetation cover to such an extent that previously stable fossil dunes have once again become active (Barth, 1999).

\subsection{Coastal Processes}

The coastline running south of Dosariyah is dominated by a series of complex coastal barriers, spits, lagoons and sabkhas. The coastal configuration comprises several headlands and embayments, which are heavily influenced by coastal processes, especially tidal patterns, wave refraction and longshore drift. Tidal patterns within the Gulf are complex with regional variations in tidal range (Barth, 2002), including two amphidromic points that have been noted where there is no tidal range. The first of these is located off the eastern Saudi Arabian 
coast to the north of Dosariyah, and the second is located off the western Abu Dhabi coast (UAE). Tidal ranges increase away from these nodes and over most of the Gulf, the tidal range offshore is $<0.6 \mathrm{~m}$ but increases to 1-2 $\mathrm{m}$ near land (Sheppard et al., 1992). At Jubail the tides mainly follow a semi-diurnal regime with a mean spring tide range of $c .1 .5 \mathrm{~m}$ and neap tidal range of $0.8 \mathrm{~m}$ (Barth, 2002).

Present-day coastal processes have been severely impacted by development and infrastructure along the coast, in the form of artificial islands, marinas and groynes, leading to sediment supply and delivery issues. In places this has led to the starvation of sediment resupply leading to erosion of the coastal barrier island and spits. At Dosariyah a coastal barrier-spit complex has developed, behind which a series of lagoons and channels have formed. These coastal features formed across coastal embayments at the mouth of the now dry sabkha inlets. At least two barriers are evident: the present barrier lies approximately $250 \mathrm{~m}$ from the coastal cliff line, while an older, former barrier abuts the land (Fig. 3). This feature lies across the entrance to the northern sabkha where it now forms a low dune. The coastal barrier deposits comprise a complex mix of beach, aeolian and washover sands. These form complex elongate hooked spits curving inland. Current coastal processes are eroding this feature because of the starvation of new sediment supply due to coastal development and the construction of breakwaters to the north. The spits and barrier islands are aligned parallel to the coast and the coastal barriers are interspersed by intertidal and lagoonal sediments. 


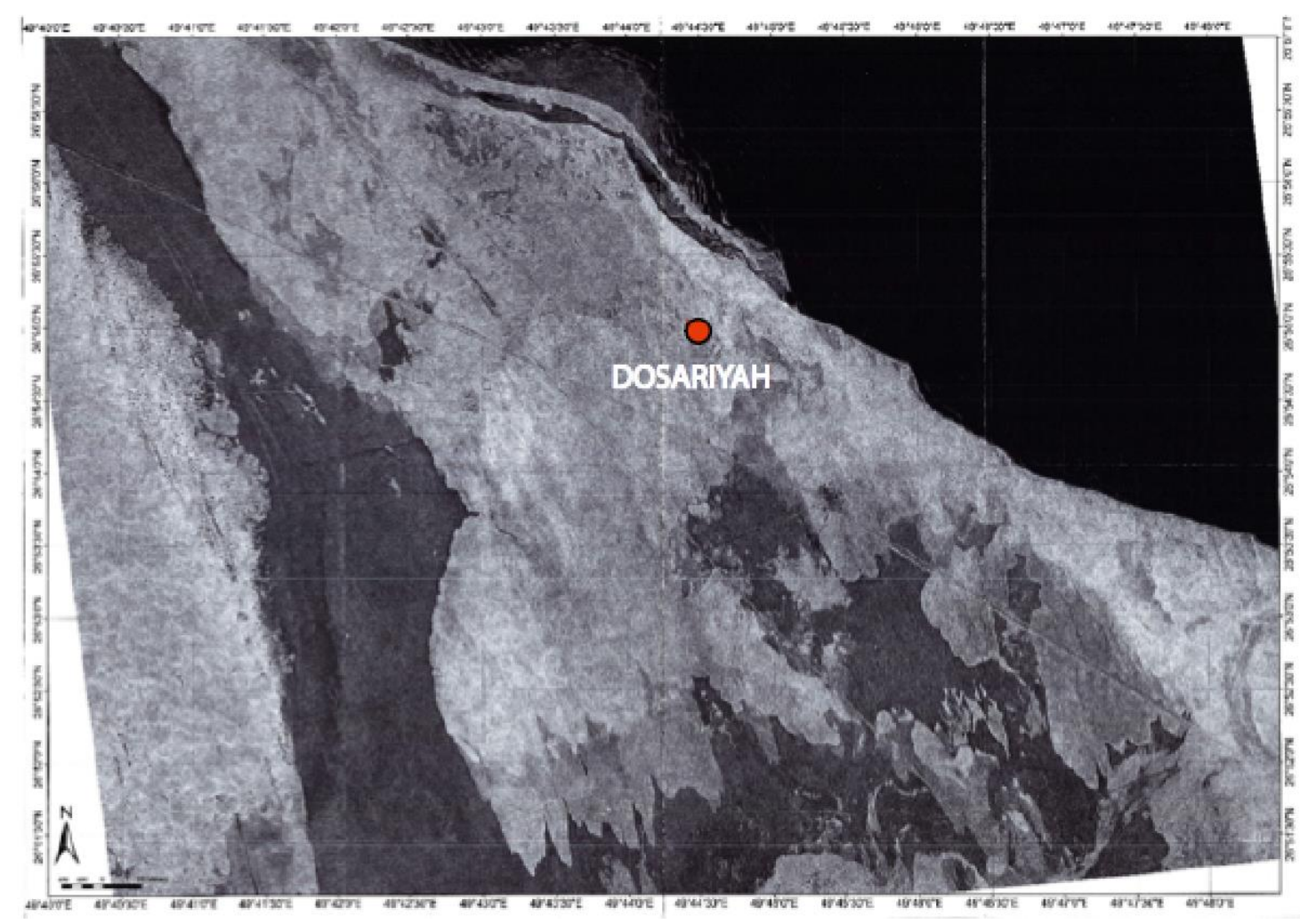

Figure 3: 1968 declassified CORONA satellite image of Dosariyah showing the site location and surrounding area comprising present and relict coastal barriers, dune areas and sabkhas

Inland, these features have largely infilled to form extensive sabkha deposits. Compared to the classic barrier-lagoon systems found in the UAE around Abu Dhabi, the Dosariyah system tends to lack carbonate mud and algal mats. This observation was previously noted by James and Little (1994), who suggest that this may be the result of groundwater influences from aquifers within the Pleistocene dune and Miocene Hadrukh bedrock formations. The sabkhas comprise flat areas, partially cemented by salt (sodium chloride) and calcium sulphate (gypsum) often forming pustulose surfaces. Two areas of sabkha are found close to the site at Dosariyah, one to the north and the other to the south. The southern sabkha is of particular importance because of its location adjacent to the Neolithic archeological site.

\subsection{Archaeology}

Dosariyah is one of the most significant Neolithic archaeological sites in the Gulf region. Early work, undertaken by Burkholder (1972), Bibby (1973) and Masry 
(1974), identified the importance of the site and in particular the significant occurrence of Ubaid pottery. Previously the occurrence of Ubaid pottery was restricted to sites in southern Mesopotamia, located more than $600 \mathrm{~km}$ away, and highlighting the importance of trade and exchange of material culture in the Gulf region during the Neolithic. The initial work at Dosariyah noted exceptional conditions of preservation at Dosariyah including animal and fish bone, bitumen, chert and plaster. Stratified archaeological deposits dating as early as the Neolithic period are infrequent in the Gulf region and sites with sufficient preservation of bone and other fragile remains, such a bitumen, are scarcer still (Drechsler, 2018; Van de Velde et al., 2015). The site, which extends over 10,000 $\mathrm{m}^{2}$, was excavated between 2010 and 2014 by the Dosariyah Archaeological Research Project (DARP) (Drechsler, 2018). The site was occupied during the Middle Neolithic, dating to the $6^{\text {th }}$ and first half of the 5 th millennium BCE ( 7200-6500 cal BP). The spectrum of material remains excavated shows unique characteristics. The lithic technology and typology are rooted in the local Arabian Middle Neolithic. Large amounts of black on buff Ubaid pottery (more than 9000 pieces) were imported from southern Mesopotamia, whilst bitumen and obsidian demonstrate exchange networks beyond the Gulf region. The importance of seafaring in the exchange of material goods along the Gulf was an important development during the Neolithic (Carter and Crawford, 2010). Subsistence strategies were mostly based on marine resources (fish, shellfish) including deep-water fishing supplemented by hunting of wild animals as well as the herding of sheep, goat and cattle (Drechsler, 2018).

\section{$3 \quad$ Methods and Materials}

\subsection{Geomorphology and Sedimentology}

The Neolithic site of Dosariyah is situated on an area of higher ground, c. $5 \mathrm{~m}$ above mean sea level (asl), surrounded on three sides by low-lying sabkha and to the east by coastal dunes and the Gulf coastline. The sabkha surface in this area comprises flat, low-lying gypsiferous surfaces with coarse gypsum crystals, medium to coarse sand and abundant relict marine gastropod shells of the genus Cerithidea; a mollusc favoring an intertidal environment (Feulner and Hornby, 2006). The sabkha in this area of Jubail is unusual as it is nourished by artesian 
groundwater that appears to be important in the maintenance of this area as a salt flat (James and Little, 1994). To the south of the site the sabkha can be broadly divided into an upper, middle and lower elevation surface, with the elevation dropping towards the south away from the site. To the north of the site the higher ground is formed by Pleistocene and Holocene dune systems, and the sabkha appears to comprise one main surface that extends out to the north and west. Profiles across the site were surveyed using a total station in relation to sea level (Fig. 4). Five test pits (TP) were excavated into the sabkha deposits located to the north and south of the Dosariyah archeological site. The depths excavated were limited by the modern water table. The sediment sections were logged and described and are shown in m asl (Fig. 4). In addition, sediment exposures within the coastal dunes were mapped and logged across the site and sampled for OSL dating (quarry pit site (QP1) and coastal section (CS)).

Profiles within these test pits were recorded and sampled for palaeoenvironmental analyses. Mass-specific, low-frequency magnetic susceptibility measurements were made on each sample using a Bartington MS2 meter with an MS2B sensor at 0.1 SI unit sensitivity (Dearing, 1999). Loss-onignition analyses followed the method described by Heiri et al. (2001). Results are reported as percentages of the dry weight. To determine grain size, samples of air-dried sediment $<2 \mathrm{~mm}$ were gently disaggregated in de-ionized water with 5\% Calgon (Sodium hexametaphosphate) and analyzed using a Malvern Mastersizer 2000. Grain size statistics are based on the logarithmic graphical measures of the (original) Folk and Ward (1957) method for sorting, skewness and kurtosis. The mean particle size calculations are based on the modified Udden-Wentworth scale and are reported in microns $(\mu \mathrm{m})$. 

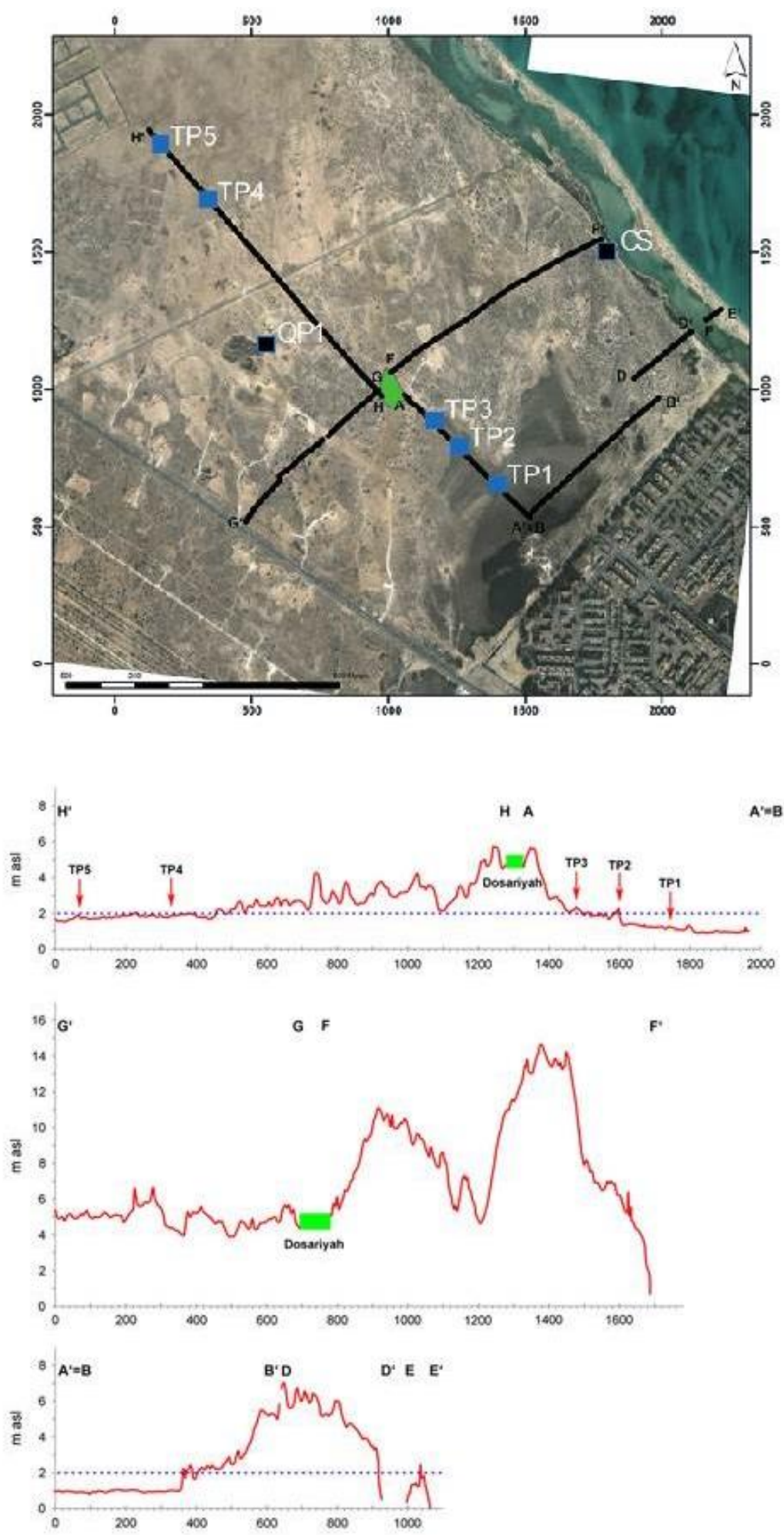

Figure 4: Satellite image showing the topographic transect profiles and locations of sampling sites TP1-5, QP1 and coastal section (CS). The Dosariyah archaeological site is shown in green. 


\subsection{Chronology}

Samples for optically stimulated luminescence (OSL) dating were collected from cleaned sections using black, opaque, light-proof tubes $(50 \mathrm{~mm}$ diameter x $200 \mathrm{~mm}$ length). Sample locations are listed in Table 1. OSL samples were prepared under subdued red light at the Royal Holloway Luminescence Laboratory. The minerogenic fraction was extracted from the bulk sample using $\mathrm{HCl}$ and $\mathrm{H}_{2} \mathrm{O}_{2}$, after which the remaining material was wet sieved to $210-180 \mu \mathrm{m}$. Quartz was extracted from this fraction using density separations at 2.62 and $2.70 \mathrm{~g} / \mathrm{cm}^{3}$ and a subsequent $\mathrm{HF}$ acid etch (23M HF for $40 \mathrm{~min}$ followed by a $10 \mathrm{M}$ $\mathrm{HCl}$ rinse), after which the remaining material was sieved at $150 \mu \mathrm{m}$ to remove partially dissolved grains. Quartz was mounted on stainless steel discs using Silkospray applied via a $5 \mathrm{~mm}$ diameter mask.

The single-aliquot regenerative-dose method (Murray and Wintle, 2000) was used to determine the equivalent dose for each sample. All measurements were carried out using a Risø TL-DA-20 instrument. Dose recovery experiments were performed on two samples (OSL1 and OSL3), which produced good results across a wide range of commonly adopted preheating regimes. For all subsequent measurements, a preheat of $220^{\circ} \mathrm{C}$ for $10 \mathrm{~s}$ prior to measurement of natural/regenerated signals, and a cut-heat of $160{ }^{\circ} \mathrm{C}$ prior to measurement of the test dose signal was used. Thirty-six aliquots were measured per sample. Aliquots not yielding recycling (Murray and Wintle, 2000) or IR depletion (Duller 2003) ratios consistent with unity were rejected. The luminescence properties of the samples were poor, with 34\% of aliquots being rejected (equal numbers of aliquots failed each rejection criterion) and all aliquots yielding dim signals $(\sim 250$ counts/Gy). Similarly poor luminescence properties have been reported for a number of sites on the Arabian Peninsula (e.g. Klasen et al., 2011; Petraglia et al., 2012; Bretzke et al., 2013; Groucutt et al., 2018). Sample mean equivalent doses were calculated from the aliquots which passed the above rejection criteria.

Radioisotope concentrations were determined using ICP-MS (U and Th) and ICPAES $(K)$, and used to determine the beta and gamma dose rates using the 
conversion factors of Adamiec and Aitken (1998). Cosmic ray dose rates were calculated using site location (latitude and longitude), elevation and present-day burial depths, assuming an overburden density of $1.85 \mathrm{~g} / \mathrm{cm}^{3}$ (Prescott and Hutton, 1988). Based on their present-day moisture content, a burial moisture content of $10 \pm 2.5 \%$ was used for all samples except OSL1. The age for sample OSL1 was calculated using a burial water content of $15 \pm 5 \%$. This sample is located very close to the water table and is likely to have been below the water table (i.e. saturated, $\sim 37 \%$ water content) for a substantial part of the burial period. The uncertainty term on the water content for this sample encompasses (at $2 \sigma$ ) the driest conceivable burial conditions (freely drained sand, $\sim 5 \%$ ) and a scenario in which the sample lies below the water table for $\sim 65 \%$ of the burial period and is freely drained above the water table for the remaining $\sim 35 \%$ of the burial period. These two scenarios represent a realistic range of possible moisture contents experienced by sample OSL1 during burial. Ages for the Dosariyah OSL samples are presented in Table 1.

AMS radiocarbon dating $\left({ }^{14} \mathrm{C}\right)$ was carried out at Scottish Universities Environmental Research Centre (SUERC) and dates were determined on marine shells. Dates were calibrated using the 95\% confidence limits in Calib 7.1 using the Marine13 curve (Reimer et al., 2013) and corrected for the Gulf Marine reservoir effect using the delta $\mathrm{R}$ value of $180 \pm 53$ (Southon et al., 2002). All ages are reported in cal. BP with an error range of $2 \sigma$. Table 2 shows the radiocarbon ages for nine samples taken from the test pits.

\subsection{Mollusc Identification and Quantification}

Bulk samples ( $1 \mathrm{~kg}$ ) from $2 \mathrm{~cm}$ intervals were collected and processed for molluscan analysis from the five sample pit locations. Remains were identified using published identification guides and keys (Bosch and Bosch, 1989; Oliver, 1992; Willan, 1993; Hasan, 1994; Bosch et al., 1995; Glover and Taylor, 2001; DuPont and Al Tamimi, 2008; Jahangir et al., 2012). The assemblages from the five test pits were quantified in terms of number of identified specimens (NISP), minimum number of valves (MNV) and minimum number of individuals (MNI) based on apex and aperture presence for gastropods, and on umbo presence for 
bivalves. Bivalves were attributed to right or left sides where possible. For bivalves the recorded dimensions (shell size, below) were taken into consideration when calculating MNV and MNI.

Molluscs were measured to the nearest $0.1 \mathrm{~mm}$ using Mitutoyo Absolute Digimatic calipers. For bivalves, measurements for valve length (VL) and valve height (VH) were taken, as described by Claassen (1998). Valve depth was also measured in bivalves. For gastropods, shell height ( $\mathrm{SH})$ and width was measured, also as described by Claassen (1998). Specimens were not measured if they were not complete (e.g. with missing apex or missing or damaged apertures in the case of gastropods, and absent umbo or margin damage for bivalves). In addition to recording fragmentation, each specimen was subjected to observation for taphonomic impacts. This includes recording any evidence of predation by other animal taxa, hosting for tubeworms (e.g. Vermetidae) or any other surface modification of known or unknown origin. Molluscan taxa are often highly sensitive to variation in environmental conditions; as such, their presence, absence and relative abundance in stratified sediments can be used to aid reconstruction of past environmental conditions, and changes in these over time and space.

It is essential in the study of both recent and ancient molluscs that the use of current, accepted taxonomy is ensured. In Arabia, many molluscan taxa remain understudied, and as such, taxonomy is not always agreed upon between specialists. Ensuring a correct taxonomic identification impacts upon the environmental conditions that can be reconstructed using molluscan data. The taxonomy for molluscan species is continuously being updated, and therefore any taxonomic name listed here could be revised in the future. To avoid confusion each identified taxa will include a referral to the published source of its taxonomic description.

\subsection{Calculation of Relative Sea Levels (RSL)}

Sea-level index points (SLIPs) were used to fix the position of past RSL in time and space (sensu Tooley, 1998). The calculation of the vertical error of each SLIP 
includes the sum of all quantified or estimated height errors, including field levelling, present tide heights and interpretation of indicative meaning (total

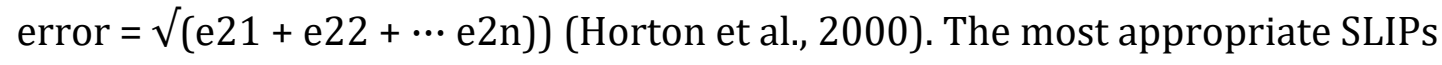
in the study area were intertidal molluscs of Dosinia sp., Pillicina cf. angela and Tellineae incarnate/wallacea. They are considered as primary SLIPS, as their elevations, ages and vertical relationships to contemporaneous tide levels (indicative meaning) can be deduced. The shells were dated by radiocarbon, while their vertical habitat range is associated with the intertidal and the uppermost metre of the shallow subtidal (Feulner and Hornby, 2006; El-Sorogy et al., 2016). Horizontal error bars indicate the maximum and minimum ages as determined by the ${ }^{14} \mathrm{C}$ calibration (Shennan et al., 2002, 2006). OSL-dated sabkha deposits are regarded as secondary SLIPs as they lack precise indicative meaning values. . Due to the nature of the sediments and the shallow depths sampled, the effects of compaction and sediment consolidation were regarded as negligible (sensu Lokier et al., 2015). The upper and lower limits calculated for the palaeomean sea level (MSL) and upper limit for the MHHW are shown alongside the radiocarbon ages in Table 2.

\section{$4 \quad$ Results}

\subsection{Quarry and Coastal Sections}

At the quarry section, (surface at $4.0 \mathrm{~m}$ asl) QP1, OSL3 yielded an age of $7.9 \pm 0.5 \mathrm{ka}$ for the quartz-rich weakly cemented sand unit $1.05 \mathrm{~m}$ below the surface (b.s.) (2.95 $\mathrm{m}$ asl) (Table 1). The upper carbonate-rich cemented unit with up to $50 \%$ ooids was dated to $3.1 \pm 0.2 \mathrm{ka}$ (QP1, OSL4) at $0.55 \mathrm{~m}$ depth (3.45 $\mathrm{m}$ asl). The quartz-rich sand unit below the carbonate-rich aeolianite cap unit from the coastal section was dated to $7.1 \pm 0.5 \mathrm{ka}$ (Coastal Section, OSL5, 1.6 $\mathrm{m}$ asl). The ages and differences in the composition of the two sediment units imply that they were formed in two phases of deposition with a break in sedimentation sometime in between. The lower unit is aeolian in origin and derived from quartz and other siliciclastic terrestrial sources with minor carbonate elements. The sediments in the upper unit, rich in ooids, were originally derived from a shallow marine origin and transported by aeolian processes. The stratigraphy of the five test pits excavated are shown in Figure 5 and are presented in $\mathrm{cm}$ asl. 
Table 1. Summary dosimetry and OSL dating results.

\begin{tabular}{|c|c|c|c|c|c|c|c|c|c|c|c|c|}
\hline \multirow[t]{2}{*}{ Sample } & \multirow[t]{2}{*}{ Sample details } & \multicolumn{3}{|c|}{ Radionuclide concentrations } & \multirow{2}{*}{$\begin{array}{l}\text { Sample } \\
\text { depth } \\
\text { (m) }\end{array}$} & \multirow{2}{*}{$\begin{array}{l}\text { Water } \\
\text { content } \\
(\%)\end{array}$} & \multirow{2}{*}{$\begin{array}{l}\text { OSL sample } \\
\text { grain size } \\
(\mu \mathrm{m})\end{array}$} & \multirow{2}{*}{$\begin{array}{l}\text { Cosmic } \\
\text { dose rate } \\
\text { (Gyka) }\end{array}$} & \multirow{2}{*}{$\begin{array}{l}\text { Dose rate } \\
\text { (Gyka) }\end{array}$} & \multirow{2}{*}{$\begin{array}{l}\text { Equivalent } \\
\text { Dose } \\
\text { (Gy) }\end{array}$} & \multirow{2}{*}{$\begin{array}{c}\mathrm{n} \\
\text { (accept) }\end{array}$} & \multirow{2}{*}{$\begin{array}{l}\text { Age } \\
(\mathrm{ka})^{1}\end{array}$} \\
\hline & & $\mathrm{K}(\%)$ & $\mathrm{U}(\mathrm{ppm})$ & $\mathrm{Th}(\mathrm{ppm})$ & & & & & & & & \\
\hline OSL1 & Dosariyah (TP3) & $0.90 \pm 0.09$ & $0.89=0.09$ & $1.67 \pm 0.17$ & $1.3 \pm 0.2$ & $15 \pm 5$ & $212-180$ & $0.169 \pm 0.004$ & $1.12 \pm 0.07$ & $7.14 \pm 0.34$ & 27 & $6.4 \pm 0.5$ \\
\hline OSL2 & Dosariyah (TP3) & $0.41=0.04$ & $2.00=0.20$ & $0.67 \pm 0.07$ & $0.35=0.2$ & $10=2.5$ & $212-180$ & $0.212=0.027$ & $0.98 \div 0.05$ & $1.23=0.12$ & 22 & $1.3 \neq 0.1$ \\
\hline OSL3 3 & Dosariyah (QP1) & $0.28 \pm 0.03$ & $1.81 \pm 0.18$ & $4.80=0.48$ & $1.1 \pm 0.2$ & $10=2.5$ & $212-180$ & $0.173 \pm 0.005$ & $1.05 \pm 0.05$ & $8.33 \pm 0.41$ & 21 & $7.9 \pm 0.5$ \\
\hline OSLA & Dosariyah (QP1) & $0.47 \pm 0.05$ & $1.67 \pm 0.17$ & $0.62=0.06$ & $0.5 \pm 0.2$ & $10=2.5$ & $212-180$ & $0.199=0.018$ & $0.95 \pm 0.05$ & $2.95=0.16$ & 22 & $3.1=0.2$ \\
\hline OSLS & Dosariyah (coastal section) & $0.90=0.09$ & $0.74 \pm 0.07$ & $1.80=0.18$ & $0.5 \pm 0.2$ & $10=2.5$ & $212-180$ & $0.199 \pm 0.018$ & $1.18 \div 0.07$ & $8.36 \pm 0.33$ & 27 & $7.1 \pm 0.5$ \\
\hline
\end{tabular}

Table 2: Radiocarbon dates from the palaeoenvironmental sections

\begin{tabular}{|c|c|c|c|c|c|c|c|c|c|c|c|c|c|}
\hline \multicolumn{3}{|c|}{ Samples } & \multicolumn{5}{|c|}{ Reconstruction of palaeo sea level band } & \multirow[b]{2}{*}{$\begin{array}{l}\text { Lab ID } \\
\text { (SUERC) }\end{array}$} & \multirow[b]{2}{*}{ Material } & \multirow[b]{2}{*}{${ }^{14} \mathrm{CBP}$} & \multirow[b]{2}{*}{$\begin{array}{l}\delta^{13} \mathrm{C} \\
(\% 0)\end{array}$} & \multicolumn{2}{|c|}{ Calibrated ages } \\
\hline Sample name & $\begin{array}{c}\text { Depth } \\
\text { (m b.s.) }\end{array}$ & $\begin{array}{l}\text { Elevation } \\
\text { (m a. MSL) }\end{array}$ & $\begin{array}{l}\text { Upper Limit } \\
\text { (m a. MSL) }\end{array}$ & $\begin{array}{l}\text { Lower Limit } \\
\text { (m a. MSL) }\end{array}$ & $\begin{array}{l}\text { Upper limit } \\
\text { palaeo } \\
\text { MHHW } \\
\text { (m a. MSL) }\end{array}$ & $\begin{array}{l}\text { Upper limit } \\
\text { palaeo MSL } \\
\text { (m a. MSL) }\end{array}$ & $\begin{array}{l}\text { Lower limit } \\
\text { palaeo MSL } \\
\text { (m a. MSL) }\end{array}$ & & & & & $\begin{array}{l}\text { Age cal } \\
\text { BCE }(2 \sigma)\end{array}$ & $\begin{array}{c}\text { Age cal BP } \\
(2 \sigma)\end{array}$ \\
\hline DOS 14/8TP5 & 0.32 & 1.39 & 1.53 & -0.44 & 3.45 & 2.92 & 0.95 & 54501 & Pillucina of angela/Dosinia atto & $4266 \pm 30$ & 1.2 & $2386-2000$ & 3949-4335 \\
\hline DOS 14/9TP5 & 0.48 & 1.23 & 1.53 & -0.44 & 3.29 & 2.76 & 0.79 & 54502 & Dosinia cf.atto & $4482 \pm 30$ & 1.8 & $2651-2286$ & $4235-4600$ \\
\hline DOS 14/2TP1 & 0.48 & 0.84 & 1.53 & -0.44 & 2.90 & 2.37 & 0.40 & 54492 & Tellinia incamate/wallaceoe & $4690 \pm 30$ & 2.9 & $2885-2576$ & 4525-4834 \\
\hline DOS 14/1TP1 & 0.42 & 0.90 & 1.53 & -0.44 & 2.96 & 2.43 & 0.46 & 54491 & Tellinia incamate/wallacea & $4706 \pm 30$ & 2.9 & $2899-2586$ & 4535-4848 \\
\hline DOS 14/4TP4 & 0.22 & 1.69 & 1.53 & -0.44 & 3.75 & 3.22 & 1.25 & 54497 & Dosinia cf. alta & $5273 \pm 30$ & 2.3 & $3624-3360$ & 5309-5573 \\
\hline DOS 14/5TP4 & 0.64 & 1.27 & 1.53 & -0.44 & 3.33 & 2.80 & 0.83 & 54498 & Dosinia cf. alto & $5642 \pm 30$ & 2.4 & 4026-3734 & 5683-5975 \\
\hline DOS 14/3TP2 & 0.45 & 1.09 & 1.53 & -0.44 & 3.13 & 2.60 & 0.63 & 54496 & Pillucina of ongelo/Dosinio atto & $5976 \pm 30$ & 2.6 & $4399-4085$ & 6034-6046 \\
\hline DOS 14/6TP4 & 0.86 & 1.05 & 1.53 & -0.44 & 3.11 & 2.58 & 0.61 & 54499 & Dosinia cf. alto & $6139 \pm 30$ & 2.1 & $4540-4318$ & $6267-6489$ \\
\hline DOS 14/7TP4 & 1.17 & 0.74 & 1.53 & -0.44 & 2.80 & 2.27 & 0.30 & 54500 & Dosinia cf. alto & $6444 \pm 31$ & 2.6 & $4929-4610$ & 6559-6878 \\
\hline
\end{tabular}

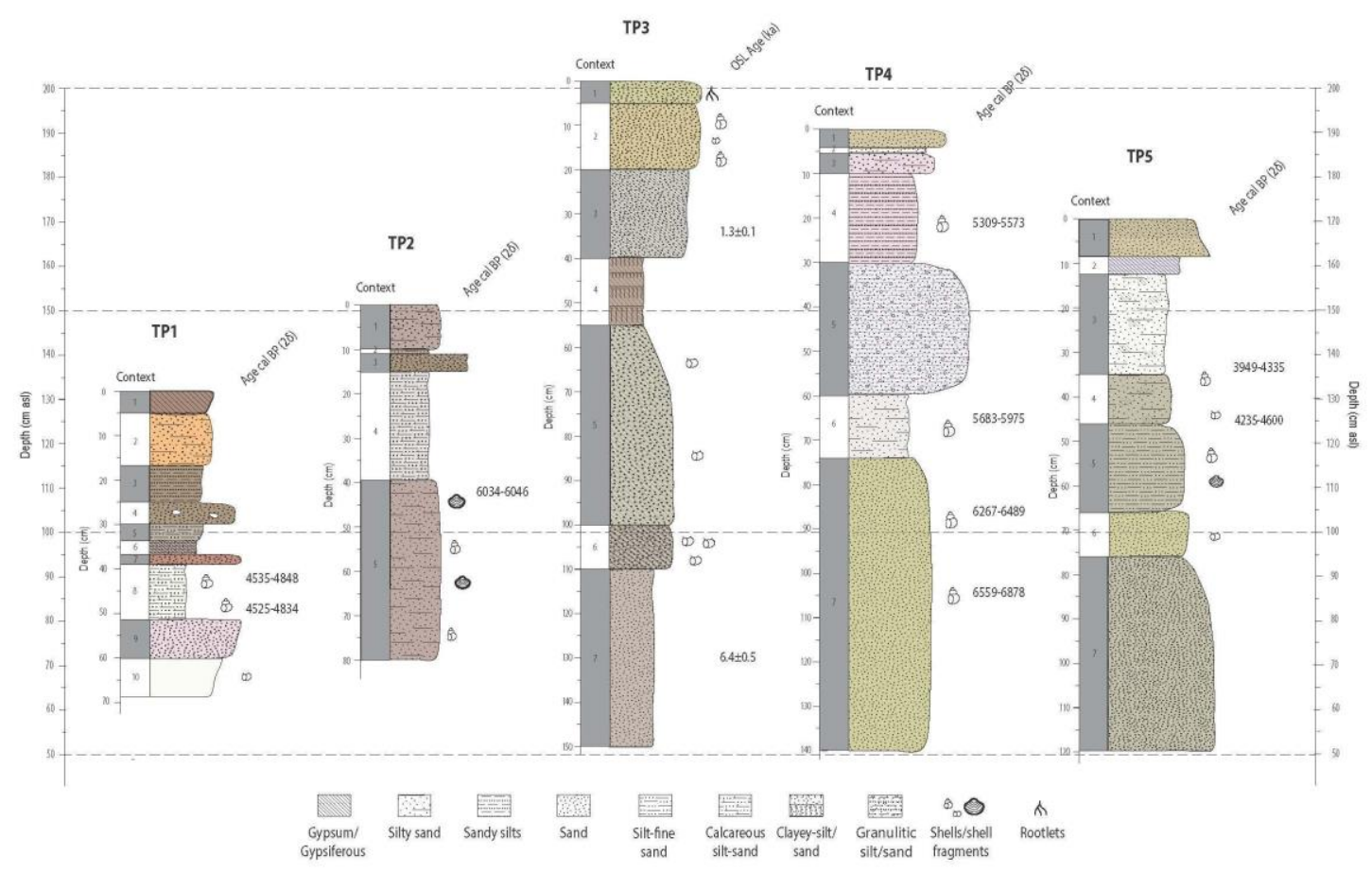

Figure 5. Test pit profiles from the southern sabkha (TP1, TP2, TP3) and northern sabkha (TP4, TP5); all sections are presented in $\mathrm{cm}$ asl. 


\subsection{Section TP1}

TP1 is situated at a point where a tongue of higher ground forms a low promontory extending out into the northwestern area of the southern sabkha (Fig. 4). The surface height was measured at $132 \mathrm{~cm}$ asl and the water table was reached at $70 \mathrm{~cm}$ b.s.. TP1 exhibited a very well defined stratigraphic sequence, with medium to coarse aeolian sands (in a lagoonal context) overlying a highly distinctive white fine silt unit with a sticky consistency and a very pure composition (Fig. 6). A total of 119 mollusk shells were recovered from the three samples taken from TP1 (Fig. 7). These represented six individual gastropods and 113 bivalve valves. Gastropods are represented by one taxa of the Genus Cerithidea. Bivalves are represented by at least three taxa from two families, Ungulinidae and Tellinidae. Bivalves are more frequent than gastropods in the TP1 sequence, within which Tellina cf. arsinoensis and Tellina incarnata/wallaceae are most abundant in the assemblage. Unlike the molluscan remains from the other test pits at Dosariyah, those from TP1 included substantial amounts of fragmentary material, especially at 46-50 cm, which contained 127 fragments of unidentified tellinid remains. Two radiocarbon samples were measured at $90 \mathrm{~cm}$ asl ( $42 \mathrm{~cm}$ b.s.) and $84 \mathrm{~cm}$ asl (48 cm b.s.) which yielded ages of 4535-4848 cal. BP and 4525-4834 cal. BP (Table 2). 

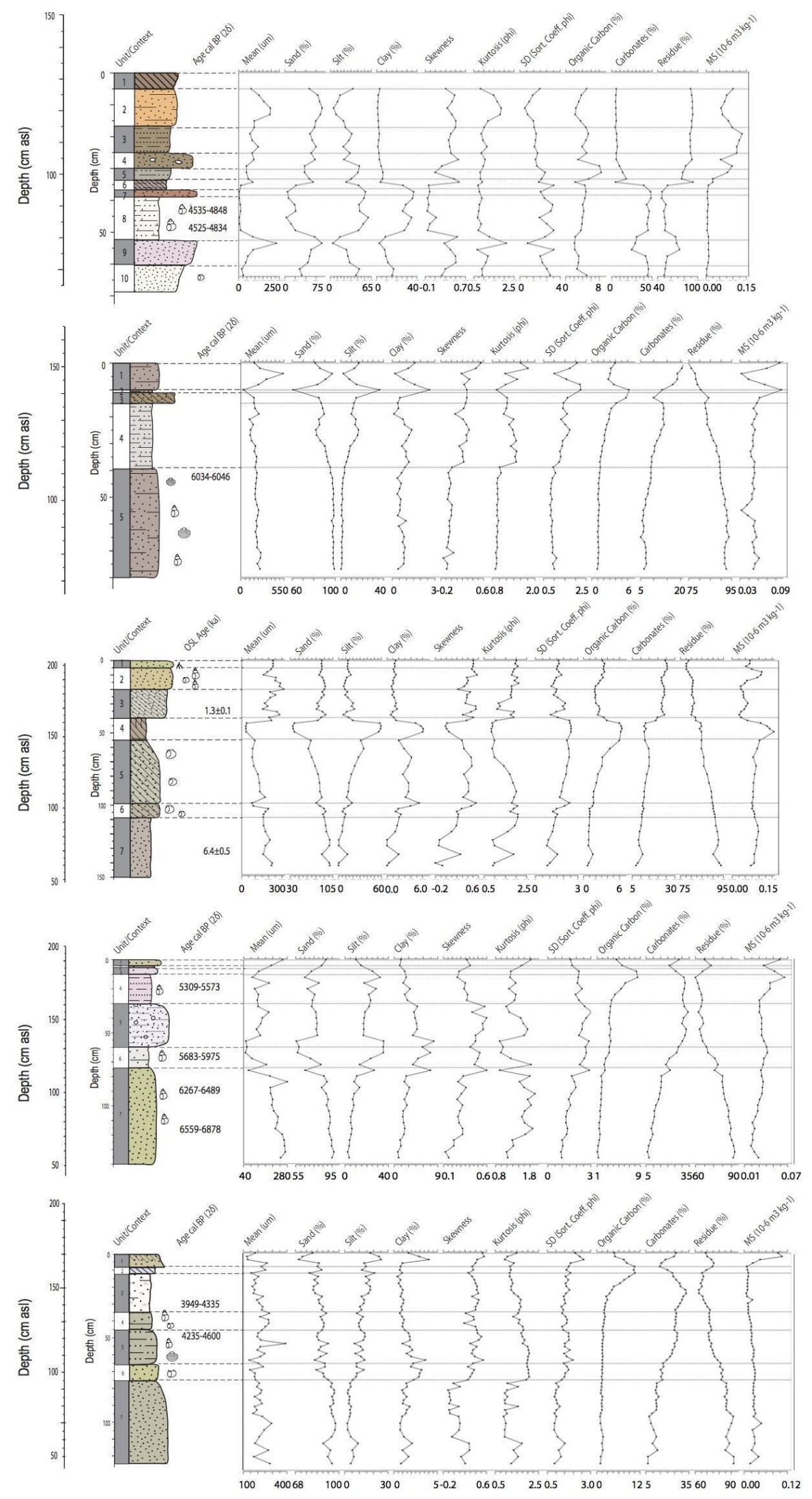

TP5

Figure 6: Sedimentology and multiproxy palaeoenvironmental record from TP1-5 

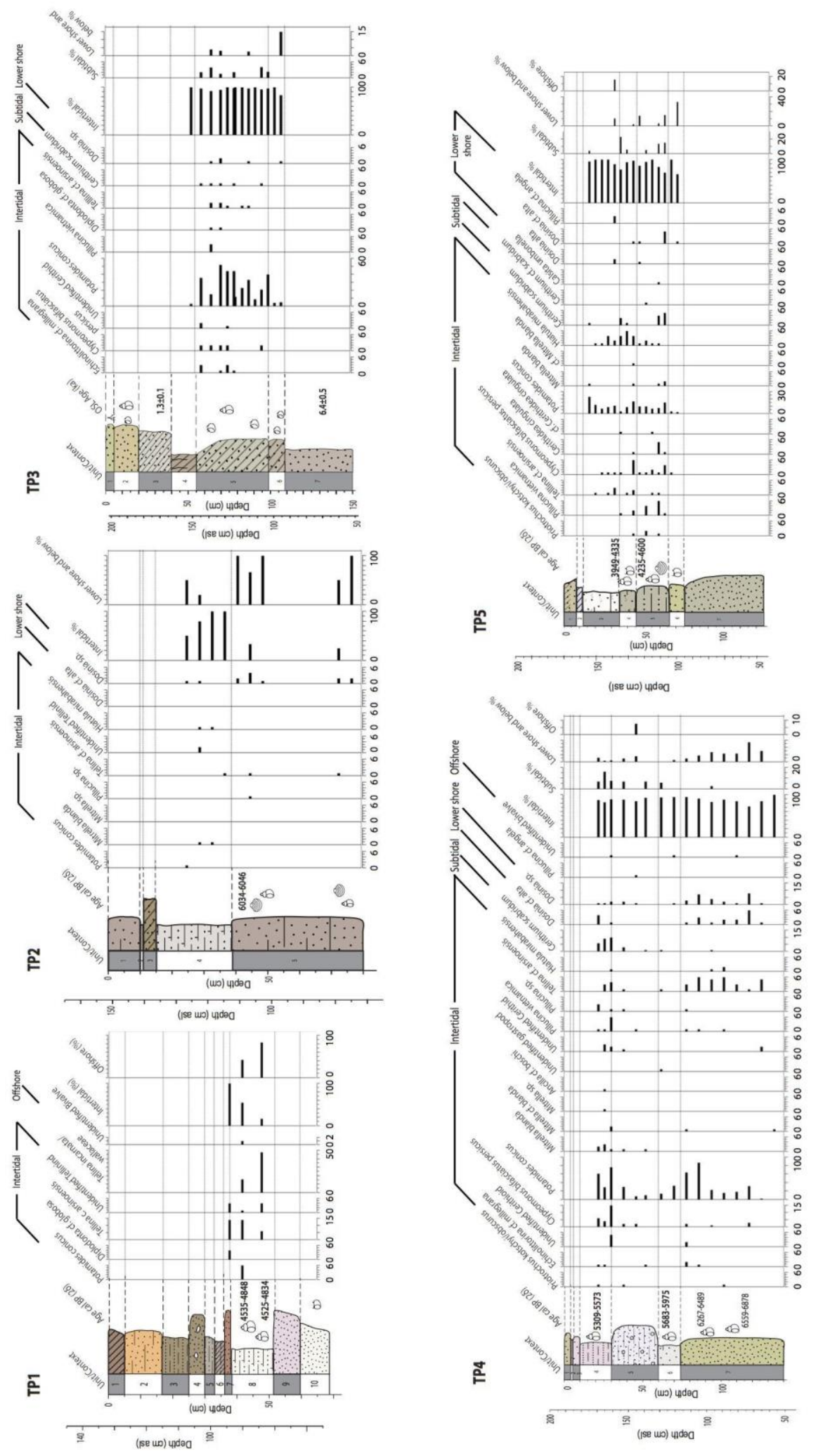

Figure 7: Mollusc records from TP1-TP5 
The sequence in TP1 shows a very marked change in depositional environment from fine-grained silts in the lowermost Unit 10, to medium- to coarse-grained sands in Unit 9, returning to fine-grained clays (up to 30\%) and silts (up to 50\%) in Unit 8 with medium- to coarse-grained sands in the overlying Units 7 to 2 . Unit 8, which comprised homogeneous carbonate-rich fine-grained clays and silts, contained molluscs in life position. The silty sediments in Unit 8 and Unit 7 are very poorly sorted, platykurtic and near symmetrical, indicative of a very lowenergy environment where silts and clays have settled out of suspension in a marine-proximal environment with marine shells deposited in life position. In Unit 8 the layers of abundant marine bivalves in life position mark the stabilization of water levels at a depth conducive to supporting bivalve communities in higher numbers. A deeper water marine environment is suggested by the presence of Tellina incarnate/wallaceae, which is the most abundant species in Unit 8. The molluscs present in the upper part of Unit 8 and Unit 7 suggest a shallowing up sequence with an increase in the presence of intertidal species including Potamides conicus, Diplodonta cf. globosa and Tellina cf. arsinoenis. Both radiocarbon dates are statistically identical and place Unit 8 at c. 4535-4850 cal. BP. The bulk of the lower Units 10 to 8 were laid down during a marine transgression event when a sufficient water column existed for the deposition of clays and silts and the development of a sheltered lagoon. The sands of Units 6 to 2 indicate a reduction of water depth and the contraction of the lagoonal shoreline allowing sand to be introduced to the lagoonal environment by aeolian processes. No molluscs were present in these units. The upper $10 \mathrm{~cm}$ of the sabkha profile (Unit 1) and the present-day surface comprises well-cemented gypsiferous sands, gypsum crystals, salt heave features and abundant cerithid shells. The latter are consistent with intertidal sand flats, signifying a coastal marginal environment during the sea level regressive event.

\subsection{Section TP2 (Southern Sabkha)}

TP2 was located at the northwest margin of the middle sabkha, at the point where this level interdigitates with higher sabkha deposits. The surface was $152 \mathrm{~cm}$ asl and a single radiocarbon age determination was made from a sample

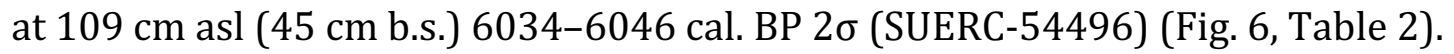


Only 36 mollusc shells were recovered from the eleven samples taken from TP2 (Fig. 7). These are represented by four individual gastropods and 32 bivalve valves. Gastropods are represented by at least two taxa of two families Potamididae and Columbellida. Bivalves are represented by at least five taxa, from four families - Lucinidae, Tellinidae, Psammobiidae and Veneridae. Bivalves are more frequent than gastropods in the TP2 sequence, within which Dosinia sp. and Tellina cf. arsinoensis are most abundant in the assemblage, though both are still only present in relatively low numbers.

The oldest, basal context (Unit 5) comprises medium-fine near symmetrical, mesokurtic, moderately sorted aeolian sands that have been reworked and deposited into a marine marginal environment, most likely at the fringes of an intertidal flat during a transgressive phase. Fine silts and the presence of a few shells including Dosinia cf. alba indicate a shallow to moderate water depth, suggesting a tidal influence close to the site at Dosariyah to the north. Shells are absent between 72 and $50 \mathrm{~cm}$ b.s. (80-102 cm asl) suggesting a contraction in marine/lagoonal waters is evident up-profile (Unit 5). The molluscan assemblage records lower shore and intertidal taxa during the main transgression phase in the upper part of Unit 5 between 50 and $39 \mathrm{~cm}$ b.s. (102$113 \mathrm{~cm}$ asl) dated to 6034-6046 cal. BP with a change to intertidal taxa in Unit 4 (39-15 cm b.s., 113-137 cm asl). The sediments in Unit 4 most likely represent sediment infilling and a lateral shift in environment. Unit 3 indicates an intertidal sand flat and the development of a sabkha from $\sim 15 \mathrm{~cm}$ b.s. $(137 \mathrm{~cm}$ asl, Units 3 and 2).

The depth for the development of sabkha occurred at $135 \mathrm{~cm}$ asl in TP2 and $\sim 138 \mathrm{~cm}$ asl in TP4. A switch to aeolian dominated sands is seen in Unit 2, with a disturbed upper layer representing recent to sub-recent turbation of the sabkha surface. The presence of artesian water in the area has resulted in a persistent gypsiferous/halite surface as hydraulic pressure forces (brackish) groundwater up through gypsiferous sediments. 


\subsection{Section TP3 (Southern Sabkha)}

TP3 was located at the northern fringes of the upper sabkha surface, closest to the site of Dosariyah. No samples were radiocarbon dated from this pit, but two OSL ages were measured (Table 1). The sequence recorded in TP3 (Fig. 6) shows seven lithological units with the area close to the site changing markedly in terms of the environments present and the influence of marine inundation. In total, 387 mollusc and mollusc fragments were recovered from 14 samples taken from TP3. These represented 369 individual gastropods and 18 bivalve valves. Gastropods are represented by at least five taxa of four families - Litterinidae, Cerithiidae, Potamididae, and Vermetidae. Bivalves are also represented by at least five taxa, but from five families - Lucinidae, Ungulinidae, Tellinidae, Psammobiidae and Veneridae (Fig. 7).

The lower part of Unit 7 indicates aeolian sedimentation with the deposition of fine, coarse-skewed, mesokurtic, moderately to poorly sorted, sands, which fine up the sequence. This unit is dated to $6.4 \pm 0.5 \mathrm{ka}$ (OSL1 TP3). Organic content is characteristically low at c. $1.5 \%$, while molluscs are absent. At around $110 \mathrm{~cm}$ b.s. (92 cm asl) the presence of molluscs occurs from Unit 6 with a continued fining-up of sediments and an increase in clays and silts. The gastropod Potamides conicus (Potamididae) is by far the most abundant taxa throughout the TP 3 sequence. The molluscan assemblage mainly represents an intertidal environment dominated by Potamididae conicus with some subtidal and lower shore elements but these occur in low frequencies. This marks a phase of marine transgression and a switch to an intertidal environment. This continues into Unit 5 until around $60 \mathrm{~cm}$ b.s. (142 cm asl). The sediments are fine-skewed to strongly fine-skewed, very leptokurtic and poorly sorted fine to very fine sands, indicating slow or standing water, probably at the fringes of a lagoon. The subsequent lowering of sea level and the development of a sabkha, as indicated by the increased values for magnetic susceptibility and organic content and the peaks in clay and silt, are shown in Unit 4. Unit 3 represents the possible interdigitation between wind-blown sands and marginal marine sediments. An OSL date of $1.3 \pm 0.1 \mathrm{ka}$ (OSL2 TP3) was determined from this unit. Unit 2 
denotes the development of sabkha while Units 3 and 1 represent wind-blown sands.

\subsection{Section TP 4 (Northern Sabkha)}

TP4 was situated at the southern margin of the northern sabkha $1.91 \mathrm{~m}$ asl, where it is overlain by dune sands (Fig. 6). Four radiocarbon dates were measured from marine shell samples of Dosinia cf. alta (Table 2). In total, 749 mollusks and mollusk fragments were recovered from 16 samples. These represented 615 individual gastropods and 134 bivalve valves. Gastropods are represented by at least nine taxa of six families - Trochidae, Littorinidae, Cerithiidae, Potamididae, Columbellidae and Olividae. Bivalves are also represented by at least five taxa, but from four families - Lucinidae, Tellinidae, Psammobiidae and Veneridae. The gastropod Potamides conicus (Potamididae) is by far the most abundant taxon throughout the TP 4 sequence (Fig. 7).

The northern sabkha joins a much larger area of low, flat ground that extends over a very wide area of sabkha to the north and west of Dosariyah. Unit 7 represents interdigitation between wind-blown sands and marginal marine facies. The lowest age from Unit 7 at $74 \mathrm{~cm}$ asl $(116-118 \mathrm{~cm}$ b.s.) gave a date of 6559-6878 cal. BP during the phase of transgression. At $105 \mathrm{~cm}$ asl $(84-88 \mathrm{~cm}$ b.s.) the ${ }^{14} \mathrm{C}$ age of 6267-6489 cal. BP occurs during the final stage of the transgression in Unit 7. The molluscan assemblage records intertidal species dominated by Potamides conicus, which accounts for c. 20-30\% below $95 \mathrm{~cm}$ b.s. (96 cm asl) and increases to $60-80 \%$ in the upper part of Unit 7. Lower shore and below taxa comprise Dosinia sp. and Dosinia cf. alta. These account for c. $25 \%$ of the assemblage in the lower parts of the unit and steadily decrease upunit to c. 5\% at the top of Unit 7 (Fig. 7).

Unit 6 represents the development of lower-energy, tidal flats with the disappearance of lower shore and below species, a decline in intertidal taxa and with Potamides conicus values declining to less than $20 \%$. A ${ }^{14} \mathrm{C}$ age of $5683-$ $5975 \mathrm{cal}$. BP $2 \sigma$ (SUERC-54498) dates this phase at $127 \mathrm{~cm}$ asl (62-66 cm b.s.). Units 5 and 4 display an increase in depositional energy with marine elements, 
indicating to either a possible second phase of transgression, as suggested by Boucharlat et al. (1991) for at sea level record at Sharjah, UAE, or more likely due to lateral changes with the opening of a sheltering barrier leading to higher energy conditions behind, possibly associated with a storm event. Intertidal taxa dominate in Units 4 and 5 with Potamides conicus and Clypepmorus bifasciatus persicus the main species represented in Unit 5. Other intertidal species that increase in Unit 4 include Mitrella blanda, Pillucina vietnamica, Tellia cf. arsinoensis and Echinolittorina cf. millegrana. The subtidal species Cerithium scabridum appears throughout both units with values increasing to c. $10 \%$ in Unit 4. Lower shore and below species reappear from $42 \mathrm{~cm}$ b.s. (142 cm asl) with Dosinia sp. and Dosinia cf. alta present. The lower part of Unit 5 represents the development of lagoonal marginal facies, while the upper part of Unit 5 and Unit 4 represent the interdigitation of wind-blown sands with marginal marine facies. Unit 4 was ${ }^{14} \mathrm{C}$ dated to $5309-5573 \mathrm{cal}$. BP at $169 \mathrm{~cm}$ asl $(20-24 \mathrm{~cm}$ b.s.). The presence of cerithid gastropods in Unit 4 suggests intertidal conditions and that this area was never completely inundated, but high-stand sea levels may have resulted in a shallow marginal water depth into which wind-blown sands were laid down. Following a gradual lowering of sea level in the upper part of Unit 4, a salt flat developed in this location (Units 3 to 1), increasingly dominated by groundwater rather than direct marine influence.

\subsection{Section TP5 (Northern Sabkha)}

TP5 was located approximately $1200 \mathrm{~m}$ from the Dosariyah archeological site on the northern sabkha. Two radiocarbon samples were dated at $123 \mathrm{~cm}$ asl $(48 \mathrm{~cm}$ b.s.) and $139 \mathrm{~cm}$ asl (32 cm b.s.) and yielded ages of 4235-4600 cal. BP and 3949-4335 cal. BP (Table 2). In total, 292 mollusc and mollusc fragments were recovered from 16 samples taken from TP5. These represented 203 individual gastropods and 68 bivalve valves. Gastropods are represented by at least six taxa of four families - Trochidae, Cerithiidae, Potamididae, and Columbellidae. Bivalves are also represented by at least six taxa of four families - Lucinidae, Tellinidae, Psammobiidae and Veneridae. The gastropod Potamides conicus (Potamididae) is by far the most abundant taxon throughout the TP 5 sequence. 
Seven sediment units were identified from TP5 (Fig. 6). Unit 7 represents the deposition of aeolian sands, which are coarser towards the base of the unit (385$200 \mu \mathrm{m}$ ) and account for at least $94 \%$ of the sediment in the unit. No molluscs were present in Unit 7. Unit 6 marks the onset of marine transgression and an increase in RSL, with molluscs first appearing in very low numbers, featuring intertidal cerithids and lower tidal species Dosinia cf. alta present (Fig. 7). Units 5 and 4 show increasingly large proportions of intact marine bivalves, often recovered in life position, indicating a strong marine influence at this time with RSL rising high enough to inundate this area. The assemblage is dominated by intertidal species with Priotrochus kotschyi/obscurus, Pillucina vietnamica, Clypeomorus bifasciatus persicus, Potamides conicus present. Hiatula mirbahensis peaks in Unit 4 to c. $6 \%$. Subtidal taxa include Cerithium scabridum in the lower part of Unit 5 and the upper part of Unit 4 only. Lower shore taxa include Dosinia sp. and Calista umbonella. Unit 5 was dated to 4235-4600 cal. BP. Molluscs in Unit 3 are almost entirely dominated by intertidal taxa with Potamides conicus accounting for c. $25 \%$. This unit indicates the development of large intertidal salt and sand flats dominated by the presence of intertidal taxa, which favors these periodically inundated habitats. The base of Unit 3 was dated to 3949-4335 cal. BP. As RSL fell to roughly the modern-day level the saltpans (Unit 2) gypsum deposits developed at or near the surface. Unit 1 reveals the input of wind-blown sand onto the groundwater-fed sabkha, driven by fluctuations of the groundwater and Stokes level.

\section{Discussion}

\subsection{Palaeoenvironments and Relative Sea Level (RSL) Changes}

During the Quaternary, RSL fluctuations would have ranged from high stands up to $10 \mathrm{~m}+$ above present levels to low stands of $-120 \mathrm{~m}$ in the Gulf (Felber et al., 1978; Lambeck, 1996; Uchupi et al., 1996; Williams and Walkden, 2002b; Engel and Brückner, 2014). Glennie (1998) suggests that at times of glacially lowered sea level, the continental shelves of the Arabian Peninsula were exposed to deflation of marine carbonates, with sediment blown inland, which led to the formation of Dammam Aeolianite in Saudi Arabia and Ghayathi Formation in the UAE. At Dosariyah, OSL ages of 7.9 ka and 7.1 ka (coastal section QS1) were 
derived from red quartz-rich aeolian sands that underlie the calcareous aeolianites indicating an early Holocene age for this unit. It is likely that the cores of the dunes (which are up to $14 \mathrm{~m}$ thick at the highest point in the mapped area) pre-date these ages and are of late Pleistocene/early Holocene age. An OSL date of $10 \pm 2 \mathrm{ka}$ was reported from a weakly developed soil within a dune $37 \mathrm{~km}$ northwest of Tanaqib in eastern Saudi Arabia, while an $11 \mathrm{~m}$ thick aeolian deposit beneath a similar palaeosol from a coastal section at Tanaqib to the north of Dosariyah, is also suggested to be late Pleistocene in age (Munro et al., 2013).

The ages suggest that the siliclastic sands were deposited in a pre-transgressive setting of the Early to mid-Holocene and are overlain by carbonates rich in ooids derived from a coastal source. The upper carbonate-rich, cemented aeolianite from the quarry section was dated to $3.1 \mathrm{ka}$ (QP1 OSL4). Glumac et al. (2012) have shown that ooids form in shallow (less than $2 \mathrm{~m}$ deep) near-shore environments extending approximately $200 \mathrm{~m}$ offshore. Typically these environments are characterized by a barren sea bottom with sand sculpted into sand ripples and sand waves. The ooid-rich material is transported onshore and lithified into aeolianite. We suggest that the carbonate-rich aeolianite at Dosariyah was formed by rapid cementation due to meteoric leaching, either during a period of increased wetness or at the saltwater/freshwater interface. These aeolianites have formed largely on the seaward side of the palaeo-dune ridges in the Jubail area, but gradually merge into unconsolidated reddercolored, less carbonate-rich dune ridges further inland. Farrant et al. (2015) suggest that dunes cement rapidly during humid periods due to the meteoric leaching of unstable aragonitic material, which is reprecipitated as intergranular, meniscus vadose cement, along with gypsum. This rapid cementation is confirmed by OSL dating, which indicates the most recent phase of carbonate dune deposition occurring during the Late Holocene, followed by cementation and stabilization (Farrant et al., 2012; 2015). While the formation of the Dammam Aeolianite has previously been suggested to be the result of carbonaterich materials deflated from the exposed Gulf basin during low sea level stands (Glennie 1998; Teller et al., 2000), we suggest that this is not the case for the 
cemented carbonate dunes at Dosariyah due to the 3.0 ka Late Holocene age for this unit and the Early Holocene ages for the underlying quartz-rich sand unit, which is at least 7-8 ka based on OSL dating. As the aeolianite is characterized by a rapid landward increase in quartz, the carbonate dunes represent a coastal dune field relatively close to the present coastline.

Engel et al. (2015) demonstrated that carbonate-rich coastal dunes do not require vast exposed shelves to form, as suggested by Glennie (1998). Instead, it is suggested that a broad beach and offshore barriers exposed at low tide, where carbonate sands are constantly compensated, are sufficient to lead to the development of bioclast-rich coastal dunes. As these conditions are very common in the southern Gulf and occur in the Dosariyah coastal location, this mechanism is proposed for the carbonate-rich dunes found at Dosariyah. The high abundance of bioclasts in the carbonate aeolianite is a good indicator for a very proximal position to beach and barrier sources as found at Dosariyah. The formation of coastal dunes under such a regime also supports the notion that the underlying quartz-rich sands accumulated from pre-transgressive sediment sources, that is, the latest Pleistocene-Early Holocene, which has a terrestrial signature with low carbonate content.

\subsection{Holocene RSL evidence from Dosariyah}

RSL variations from the Gulf region have been postulated by a number of authors and several RSL curves have been produced (Felber et al., 1978; Ridley and Seeley 1979; Al-Asfour, 1982; McClure and Vita Finzi, 1982; Bernier et al., 1995; Lambeck, 1996; Lokier et al., 2015). It should be noted that, with the exception of Lokier et al. (2015), all of the records are based on uncalibrated ${ }^{14} \mathrm{C}$ ages and without correction for marine reservoir effects on dated shell materials. Most RSL reconstructions were carried out in the 1970s and 1980s and lack precision with regard to dating control, effects of neotectonic changes, indicative meaning of sea-level index points (SLIPs), errors in elevation of sedimentary units used, and the relationship with actual tides. Differences in the use and assessment of these factors have led to several interpretations of RSL variability during the Holocene from the Gulf region. 
The RSL curve for Dosariyah is shown in Figure 8 and is based on primary SLIPs for the calibrated ${ }^{14} \mathrm{C}$ ages showing the $2 \sigma$ age ranges as horizontal error bars. The vertical errors are based on the sample elevation relative to present MSL and using an indicative meaning based on the habitat range for the species dated. The RSL curve envelope shows the range for the lowest palaeo-MSL and highest palaeo-MSL levels. In addition, the upper palaeo-MHHW level is shown as a broken line above the upper palaeo-MSL level and denotes the highest palaeotide levels excluding highest astronomical tides (HAT). The two OSL samples from TP3 (OSL $1 \&$ 2) (Units 3 and 7) are shown; they are not used to infer a vertical relationship for RSL, but as secondary SLIP to denote age, error range and elevation of these samples.

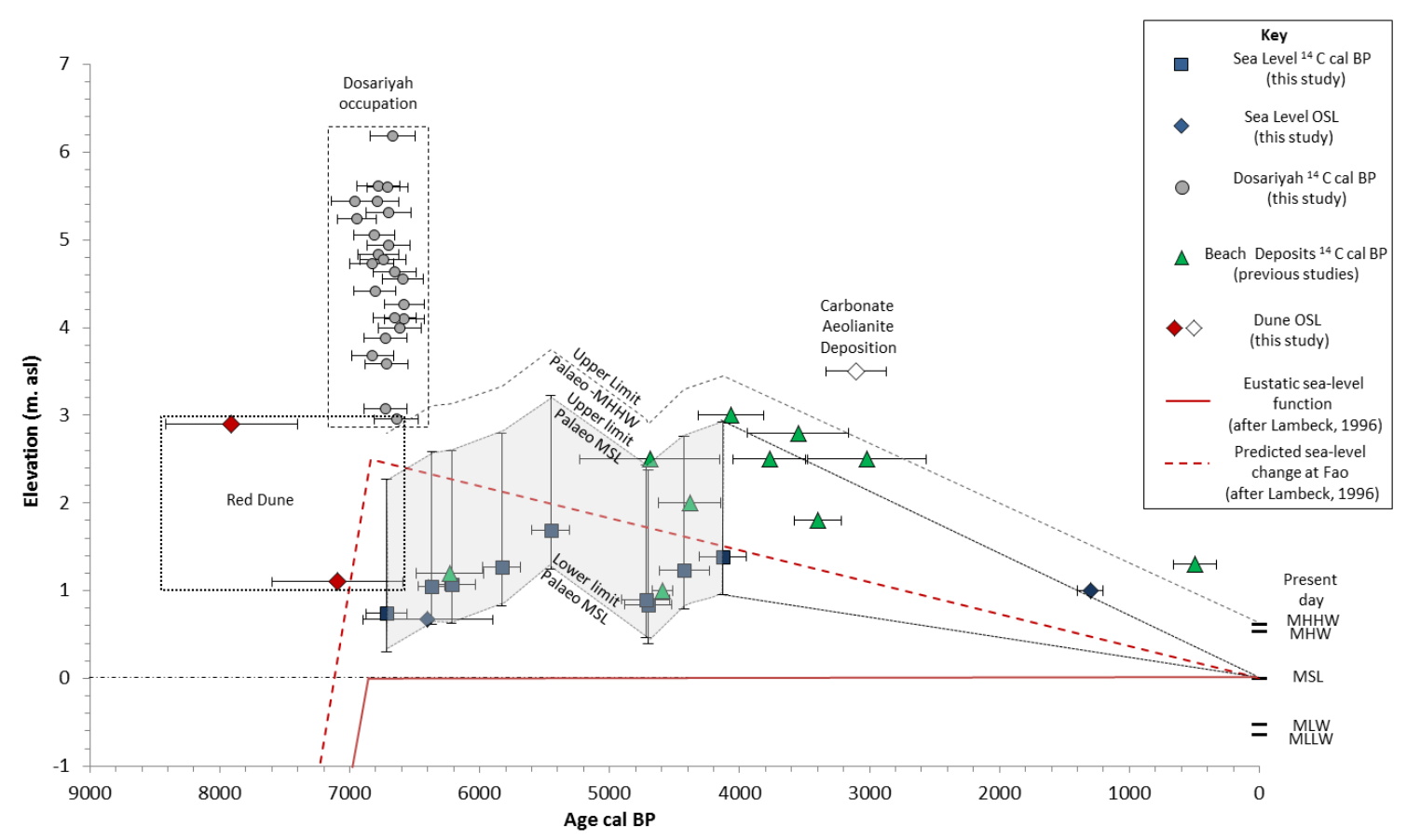

Figure 8: Relative sea level curve for the Dosariyah area since the midHolocene. The sea level band is based on sea-level index points (crosses) of relative sea level. The vertical extent of the crosses specifies the range of the assumed sea-level position associated with the sedimentary environment of the sample. The lateral extent of the crosses indicates the 


\section{$2 \sigma$ range of calibrated radiocarbon ages BP. The phase of occupation}

(dated to $2 \sigma$ range) and depth of the archeological layers is shown above sea level (grey box). The ages for dated shell beach deposits ( $2 \sigma$ range) from previously published sites along the eastern Saudi Gulf coast are plotted as asl for regional comparison (Felber et al. 1978; Ridley and Seeley 1979; McClure and Vita Finzi 1982).

In addition, a number of radiocarbon dates have previously been made on shell material collected from assumed high-stand beach deposits between Lawdhan (to the north of Jubail) and (southward) the Gulf of Salwah (Felber et al., 1978; Ridley and Seeley, 1979; McClure and Vita Finzi, 1982). The deposits ranged between $+1 \mathrm{~m}$ and $+3 \mathrm{~m}$ asl. These ages were calibrated and corrected using the $\Delta \mathrm{R} 180 \pm 53$ value for the Gulf (Southon et al., 2002), plotted at the $2 \sigma$ level and are also shown in Figure 8. The use of these ages as RSL indicators are more ambiguous as the shell material from beaches may incorporate allochthonous rather than just in situ components and therefore the host deposit may be younger than the material it contains. These ages should, therefore, be treated as maximum ages only, and they would have formed above the MHHW level most likely as a result of storm events. Figure 8 also shows the height ( $\mathrm{m}$ asl) and calibrated age range for the archaeological occupation levels at Dosariyah (Drechsler, 2018). This shows the relationship and the phase of occupation at the site and RSL at this time. In addition, eustatic sea-level function and predicted RSL for Fao at the head of the Gulf (Lambeck, 1996) are also shown. During the Holocene the predicted sea levels at Fao, located in the north of the Gulf some $350 \mathrm{~km}$ from Dosariyah, lie above the eustatic change and a high stand c. $2.5 \mathrm{~m}$ higher than today developed at c.7 ka BP (Lambeck, 1996).

From the Dosariyah record, the earliest age for the onset of marine transgression was recorded in TP4 located c.1 km away in the northern sabkha area and is marked by the presence of lower shore species, such as Dosinia alta, and intertidal taxa including Tellenia cf. arsinoensis and Potamides conicus. These species live on sandy substrates. While a small number of shells were found lower down the sequence, the taxa found are known to burrow up to $10-15 \mathrm{~cm}$ 
into sediment (Feulner and Hornby 2006). A radiocarbon age at $117 \mathrm{~cm}$ b.s. (74 cm asl) was dated to 6878-6559 cal. BP $2 \sigma$ and immediately post-dates the onset of transgression. This age corresponds to the period of occupation at Dosariyah showing a marine influence close to the site at this time. This period of marine influence continued until shortly after 6489-6267 cal. BP $2 \sigma$ (105 cm asl; $86 \mathrm{~cm}$ b.s.) during which there is a change from slack-water lagoonal sedimentation to the deposition of finer-grained clayey silts. The molluscan assemblage shows a change from lower shore and intertidal taxa, to littoral fringe intertidal conditions. This occurred between $105 \mathrm{~cm}$ asl and $127 \mathrm{~cm}$ asl

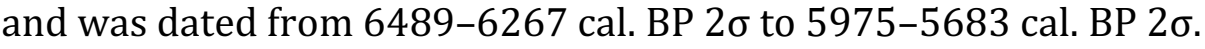

In the southern sabkha region TP2 (c. $300 \mathrm{~m}$ from the archeological site at Dosariyah) shows a similar sequence of events with a transgressive phase dated at $1.09 \mathrm{~m}$ asl at $6406-6034 \mathrm{cal}$. BP $2 \sigma$. Higher RSL (c. $1.04-1.12 \mathrm{~m}$ asl) was marked by a dominance of Dosinia sp. and Dosinia cf. alta indicating lower shore to intertidal conditions. These give way to intertidal species (c. 112-127 cm asl) indicating shallower water conditions with periodic inundation. In TP2 marine regression also led to the development of clayey silt sabkha (1.37-1.52 $\mathrm{m}$ asl). The OSL age towards the base of TP3 at $71 \mathrm{~cm}$ asl shows evidence of this transgression sometime around $6.4 \pm 0.5 \mathrm{ka}$, which within the error range corresponds with the transgressive phase shown in TP4 and TP2. The evidence from TP4 and TP2 shows that the elevations for the onset of deposition for marine sediments during the transgression occurred at 0.74 and $1.05 \mathrm{~m}$ asl respectively. The upper palaeo-MSL and upper limit for the palaeo-MHHW were c. $2.3 \mathrm{~m}$ asl and $2.80 \mathrm{~m}$ asl for TP4 and 2.60 and $3.10 \mathrm{~m}$ asl for TP2.

In the northern sabkha, TP4 shows the development of intertidal conditions at $127 \mathrm{~cm}$ asl shortly after $5683-5975 \mathrm{cal}$. BP $2 \sigma$, which is followed by the appearance of intertidal and subtidal taxa. This transgression ended at 5573$5309 \mathrm{cal}$. BP 2б. The palaeo-MSL range at this time was 1.25 to $3.22 \mathrm{~m}$ asl with the upper limit to the palaeo-MHHW at $3.75 \mathrm{~m}$ asl. After this, there is no evidence for higher relative sea levels during the Holocene in the TP4, TP3 and TP2 sections, noting that these three sections are altitudinally closest to the site. 
Evidence of later Holocene transgression is recorded in both the southern and northern sabkhas, from TP1 and TP5. In TP1 an incursion of marine waters, $0.90 \mathrm{~m}$ asl, occurred $4848-4535 \mathrm{cal}$. BP $2 \sigma$. In TP5 the onset of transgression at $\mathrm{c}$. $1.00 \mathrm{~m}$ asl occurred before $4600-4235 \mathrm{cal}$. BP $2 \sigma$ (dated at $1.23 \mathrm{~m}$ asl) and ended after 4335-3949 cal. BP $2 \sigma$ at $1.39 \mathrm{~m}$ asl. The palaeo-MSl range was 0.95 to $2.92 \mathrm{~m}$ asl and the upper limit for the palaeo-MHHW was $3.45 \mathrm{~m}$ asl. Given that there is statistical overlap at the $2 \sigma$ level for the TP1 regression and also the lower age from TP5, and that the marine transgression in TP5 started before the lower age, the two sections appear to record the same rise in sea level. After $c$. 4.2 ka BP the northern and southern sabkhas became cut off from marine incursion due to sediment infilling and also to the associated fall in RSL, with no further evidence of marine deposition. The supratidal sabkhas became subjected to aeolian as well as evaporative processes. An OSL age at $1.67 \mathrm{~m}$ asl from sabkha sediments in TP3 (Unit 3) gave an age of c. $1.3 \mathrm{ka} \mathrm{BP.} \mathrm{This} \mathrm{has} \mathrm{led} \mathrm{to} \mathrm{diagenetic}$ overprinting of gypsum crusting and deflated supratidal surfaces as seen in the uppermost layers of all the sections examined.

At the archeological site the deepest levels where artifacts were recovered differ from trench to trench, although the occupation phases all overlap chronologically, indicating a short period of occupation (Drechsler, 2018). In the southern part of the site, the anthropogenic sequence starts at $+4.7 \mathrm{~m}$ asl (c.1.5 m below the present site surface), while artifacts were found down to $+3 \mathrm{~m}$ asl (c.2.7 $\mathrm{m}$ below the surface of the site). This would indicate that without water there is $2.08 \mathrm{~m}$ difference in height between the lowest occupation levels and the lowermost intertidal sediments in TP3, and $1.55 \mathrm{~m}$ difference to the uppermost marine sediments (Unit 5) in TP3. The uppermost sabkha unit is at $2.01 \mathrm{~m}$ asl which is $0.99 \mathrm{~m}$ below the lowest occupation levels. The sabkha surface for TP2 is $1.52 \mathrm{~m}$ asl which is $1.48 \mathrm{~m}$ below the lowest occupation levels at the archaeological site. In TP4, on the northern sabkha, the onset of the transgression is recorded at $0.60 \mathrm{~m}$ asl and $1.11 \mathrm{~m}$ asl for the end $(2.40 \mathrm{~m}$ and $1.89 \mathrm{~m}$ respectively below the lowest occupation levels). 
The stratigraphic elevation data and sea-level ranges from TP 2, 3 and 4 suggest that based on the upper limits of the palaeo-MSL and palaeo-MHHW curves, the archaeological site was at, or close to sea level during the mid-Holocene transgression. During periods of higher tidal influence, including HAT, strong winter shamal conditions (Thoppil and Hogan 2010) and periodic storms surge conditions (El-Sabh and Murty 1989), it is plausible that the lower parts of the site may have become periodically inundated. Bibby (1973) recorded barnacleencrusted remnants of plaster at Dosariyah and suggested that the site was exposed to higher sea levels. This led Ridley and Seeley (1979) to propose that remnants of those walls were submerged by a RSL rise, which was then exposed by uplift or lowering of sea level, but this was contested by McClure and Vita Finzi (1982). Figure 9 shows a $+2 \mathrm{~m}$ higher than present sea level reconstruction for Dosariyah. This shows that the present-day sabkha areas would have inundated and the archeological site at Dosariyah would, in effect, have been an island at high tide or perhaps even during low tides, as was previously suggested by Bibby (1973).

The shells dated from beach ridge deposits in the eastern Saudi Gulf coast region, which were proposed as representing high-level sea level stands, mostly represent supratidal deposits formed above the MHHW, perhaps under storm surge conditions. Ten km south of Dammam, McClure and Vita Finzi (1982) dated Circe arabica shells $1.2 \mathrm{~m}$ above sea level, which yielded an age of 60066453 cal. BP $2 \sigma$ (ANU-2814,) and falls within the palaeo-MSL envelope for Dosariyah. McClure and Al-Shaikh (1993) reported additional ages from the same Ain as-Sayh complex of sites, which yielded overlapping ages in the range 6891-6407 cal. BP 2 $\sigma$. The altitudes for these samples were not reported, however, and are therefore not shown on Figure 8. The $2 \sigma$ age ranges from these dates correspond with the final occupation phase at Dosariyah and it was suggested that the site at Ain as Sayh was abandoned shortly thereafter.

Beach deposits comprising shells of Pinctada margaritifera dated by McClure and

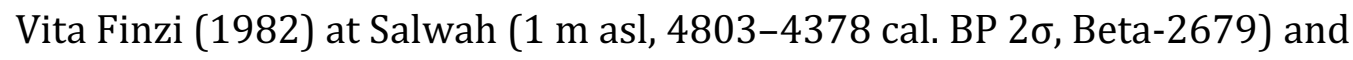
Qurayyah 2 (2 m asl, 4621-4146 cal. BP 2 $\sigma$, Beta-2682) fall within the palaeo- 
MSL envelope for Dosariyah. The dates from Cardies/Pectes shell at Ras

Tannurah (2.5 m asl, 5230-4150 cal. BP 26, IRM-3649) (Felber et al., 1978) and

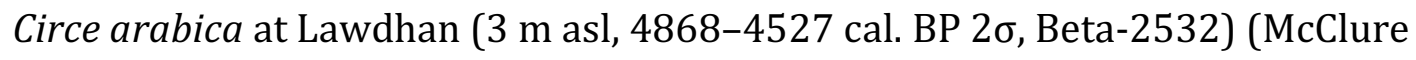
and Vita Finzi 1982) lie between the upper limit paleo-MSL and upper limit paleo-MHHW curves as dated at Dosariyah, suggesting that they were most likely formed during the highest tides or during storm surges.
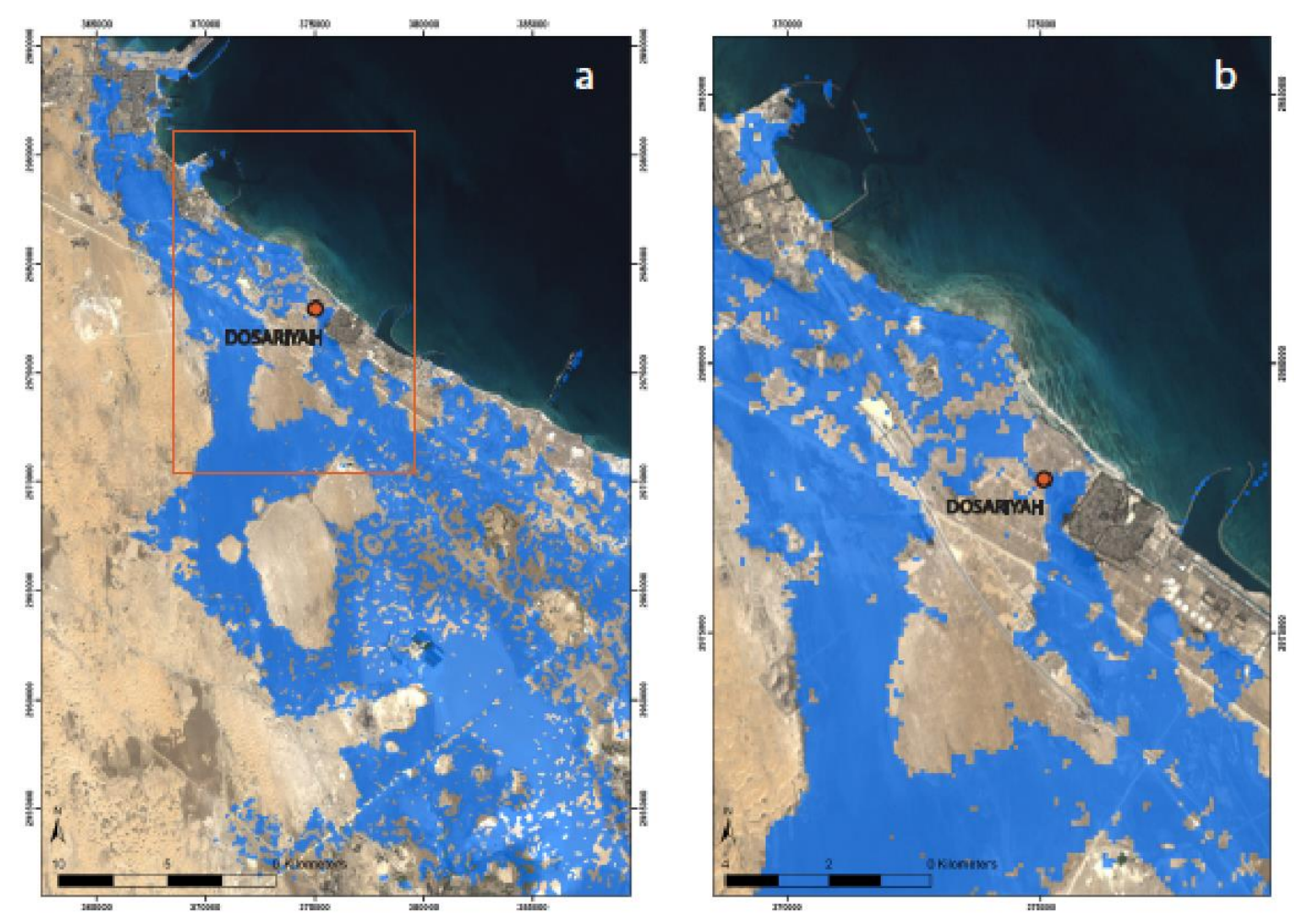

Figure 9. Sea level reconstruction using a $+2 \mathrm{~m}$ increase during the Neolithic transgression based on present-day topographic data. Red dot indicates location of Dosariyah site.

\subsection{The question of tectonics}

Neotectonic uplift and subsidence are often overlooked from most sites in the Gulf, although some attempts have been made (Ridley and Seeley 1979; McClure and Vita Finzi 1982). Given the structural geological anticlinal and synclinal complexities across the region, however, as well as the impacts of salt doming, it is difficult to calculate uplift rates for sites without direct measurements because of localized effects. Evidence of uplift in the Jubail region has been suggested by Wood et al. (2012) from OSL dating of Pleistocene age aeolian sands capped by 
marine carbonates. The lower aeolian dune sand facies yielded an age of $43.5 \pm 6.2 \mathrm{ka}$, while the upper marine facies was dated to $30.3 \pm 3.5 \mathrm{ka}$. Wood et al. (2012) suggest that the sediments were uplifted post-deposition where they were faceted into a coastal zeugen. Based on the elevation of the zeugen, at $3.9 \mathrm{~m}$ asl, they calculated an average annual uplift rate of $3.4 \mathrm{~mm} / \mathrm{yr}$. These ages, and others from coastal zeugen sites in the UAE have been challenged by Stevens et al. (2014) on the basis of their dating of similar features in the UAE, which they suggest are related to high sea-level stands during the last interglacial, and that measured accumulated dose rate differences by Wood et al. (2012) therefore yielded ages which were too young. In contrast, Stevens et al. (2014) conclude that the Fuwayrit Formation zeugen dates all conform to the last interglacial (127-87.3 ka). They postulated that RSL change was primarily controlled by global eustatic effects and shoreline progradation. Based on these ages they suggest that there is no need to invoke tectonically or halokinetic-driven uplift as proposed by Wood et al. (2012).

Pedoja et al. (2011) suggested a mean eustasy-corrected vertical uplift rate for the Gulf of $0.16 \mathrm{~mm} / \mathrm{yr}$ during the late Quaternary (since MIS 5e c. $125 \mathrm{kyr}$ ago). This does not, however, account for localized variations. At Jubail, Alothman et al. (2014) presented vertical land-motion measurements, recorded from geodetic measurements from 2011-2014, as $0.12 \pm 0.75 \mathrm{~mm} / \mathrm{yr}$. This has potentially important implications for RSL calculations at Dosariyah if a constant rate of uplift is determined for the site since it was occupied. If neotectonic uplift rates are considered, based on the $0.12 \mathrm{~mm} / \mathrm{yr}$ geodetic observations from Jubail (Alothman et al., 2014), the site would have been 0.85-0.77 $\mathrm{m}$ lower during the phase of occupation than today and thus the anthropogenic layers at the site would have been only 2.15 to $3.93 \mathrm{~m}$ asl when the site was inhabited. If the estimate of $0.16 \mathrm{~mm} / \mathrm{yr}$ uplift is applied (Pedoja et al., 2011) then the site would have been 1.14-1.02 m lower during the phase of occupation. The upper palaeoMSL estimates during occupation are c. 2.3-2.6 $\mathrm{m}$ asl and the upper limit for the palaeo-MHHW are 2.8-3.1 m asl. At maximum transgression the upper palaeoMSL estimate during occupation is c. $3.2 \mathrm{~m}$ asl and the upper limit for the palaeoMHHW is $3.75 \mathrm{~m}$ asl. If an uplift rate of c. $0.8 \mathrm{~m}$ has occurred then the RSL would 
be $0.8 \mathrm{~m}$ lower, thereby suggesting that the upper palaeo-MSL and upper limit for the palaeo-MHHW estimates during occupation would have been c. $1.8 \mathrm{~m}$ asl and c. $2.2 \mathrm{~m}$ asl. The sea level reconstructions using $\mathrm{a}+2 \mathrm{~m}$ increase during the Neolithic transgression (Figure 9) therefore provide the best estimate for the site during the phase of occupation. During the Holocene transgression maximum, the upper palaeo-MSL estimate would have been c. $2.4 \mathrm{~m}$ asl and the upper limit for the palaeo-MHHW $2.95 \mathrm{~m}$ asl. These adjusted estimates fit well with the predicted 2.5 m mean RSL calculated by Lambeck (1996) for this region of the Gulf.

\section{Conclusions}

The timing for mid-Holocene rise in RSL at Dosariyah broadly agrees with those suggested from Kuwait, Qatar and Abu Dhabi (e.g. Felber et al., 1978; Lambeck, 1996; Teller, 2000; Lokier and Steuber 2008; Engel and Brückner, 2014; Lokier et al., 2015; Reinink-Smith, 2015). This occurred prior to 6880-6560 cal. BP when the lower limit for palaeo-MSL was at least $0.30 \mathrm{~m}$ higher than today (with an upper palaeo-MSL limit of $2.27 \mathrm{~m}$ ). The sediments indicate local erosion of aeolian dune material and reworking into the overlying transgressive quartzrich carbonate units. The molluscan assemblages indicate subtidal to intertidal conditions at Dosariyah. Transgression continued until shortly after 5575-5310 cal. BP with estimated lower palaeo-MSL ranges up to $1.25 \mathrm{~m}$ asl and upper palaeo-MSL ranges up to $3.22 \mathrm{~m}$ asl, after which regression occurred with a rapid fall in sea level leading to the development of supratidal flats with sabkha development with exposure and deflation. This is in accord with the record presented by Lokier et al. (2015) from Abu Dhabi, where the same pattern and similar timings are observed.

Radiometric dating results from archeological excavations at Dosariyah suggest that the site was occupied between 7200-6500 cal. BP (Drechsler, 2018). This period corresponds to the mid-Holocene marine transgression during which rapid RSL rise occurred. The rise in sea level during the Neolithic occupation of the site, coupled with the proposed effects of neotectonic uplift, would have transformed the area around Dosariyah into an island or certainly cut it off 
tidally from the mainland during this time. We suggest that the close proximity of the site to the sea facilitated maritime exchange activities. The occupation of the site was short lived and the phase of abandonment occurred during transgression, after which sea level continued to rise reaching its peak at $\mathrm{c}$. 5600-5300 cal. BP. At Ain as Sayh, located $10 \mathrm{~km}$ south of Damman, McClure and al-Shaikh (1993) suggested that a rise in sea level during the second half of the fifth millennium BC led to several phases of displacement of the population further inland. While there is limited evidence for the inundation of the occupation layers at Dosariyah, the rise in sea level is suggested as a potential driver for the abandonment of the site. The evidence presented here supports the notion that the site became separated from the mainland, at least at high tide. However, it should be noted that during the latter half of the fifth millennium BC, the climate of the region was becoming increasingly arid, with a decrease in regional rainfall and reduced availability of fresh water affecting the availability of terrestrial resources (Preston et al., 2015; Parker et al., 2016). More work on Holocene environmental change from terrestrial records is required to test this further. Post-abandonment and after the peak in mid-Holocene transgression, sea level fell after c. $4200 \mathrm{cal}$. BP leading to the development of the modern sabkhas to the north and south of the site.

\section{Acknowledgements}

We would like to thank Dr. Ali al-Ghabban, Assistant Secretary General at the Saudi Commission for Tourism and Antiquities, for the possibility to study the Middle Neolithic site of Dosariyah within the framework of the joint SaudiGerman Dosariyah Archaeological Research Project (DARP). Work at Dosariyah would not be possible without the generous support by Jamal Omar, Saudi Commission for Tourism and Antiquities in Riyadh. We would like to thank him for his ongoing interest and advice to this project. Our warmest thanks also go to Mr. Abdulhamid al-Hashash, then head of the Dammam Archaeological Museum, for his invaluable help and encouragement to establish the project. Financial support for the project was kindly provided by the German Research Foundation (DFG), research grants DR824/1-1 and DR 824/1-2, the University of Tubingen and the Saudi Commission for Tourism and National Heritage (SCTH). 


\section{References}

Adamiec, G. and Aitken, M.J. 1998. Dose rate conversion factors: update. Ancient TL 16, 37-49.

Al-Asfour, T.A. 1982. Changing sea-level along the north coast of Kuwait Bay. Kegan Paul International.

Al-Subhi, A.M. 2010. Tide and Sea level characteristics at Juaymah, west coast of the Arabian Gulf. Marine Sciences 21, 133-149

Alkhaldi, F.M., Read, J.F. and Al-Tawil, A.A., 2020. Astronomically forced sequence development of terrestrial massive sand-sheet, inland sabkha and palustrine units, Lower Miocene Hadrukh Formation, eastern Saudi Arabia. Journal of African Earth Sciences, 171, 103914.

Alothman, A.O., Bos, M.S., Fernandes, R.M.S. and Ayhan, M.E., 2014. Sea level rise in the north-western part of the Arabian Gulf. Journal of Geodynamics 81, 105 110.

Anton, D., 1983. Modern eolian deposits of the Eastern Province of Saudi Arabia. In: M.E. Brookefield \& T.S. Ahlbrandt, (eds.). Eolian Sediments \& Processes. Amsterdam: Elsevier Science Publishers. pp. 365-378.

Anton, D., 1984. Aspects of geomorphological evolution; paleosols and dunes in Saudi Arabia. In: A.R. Jado \& J.G. Zötl, (eds.). Quaternary Period in Saudi Arabia. Volume 2. Vienna: Springer-Verlag. pp. 273-294.

Anton, D. and Vincent, P., 1986. Parabolic dunes of the Jafurah Desert, Eastern Province, Saudi Arabia. Journal of Arid Environments 11, 187-198.

Armitage, S.J., Bailey, R.M., 2005. The measured dependence of laboratory beta dose rates on sample grain size. Radiation Measurements 39, 123-127. 
Armitage, S.J., Jasim, S.A., Marks, A.E., Parker, A.G., Usik, V.I., and H.-P. Uerpmann, H.P. 2011. The southern route out of Africa: evidence for an early expansion of modern humans into Arabia. Science 331, 453-456,

Alothman, A.O., Bos, M.S., Fernandes, R.M.S., Ayhan, M.E., 2014. Sea level rise in the north-western part of the Arabian Gulf. Journal of Geodynamics, 81, 105-110.

Barth, H.J., 1998. Sebkhas als Ausdruck von Landschaftsdegradation im zentralen Küstentiefland der Ostprovinz Saudi-Arabiens. Regensburger Geographische Schriften 29.

Barth, H.J., 1999. Desertification in the Eastern Province of Saudi Arabia. Journal of Arid Environments 43, 399-410.

Barth, H.J. 2001. Characteristic of the wind regime north of Jubail, Saudi Arabia, based on high resolution data. Journal of Arid Environments 47, 387-402.

Barth, H.J., 2002. The 1991 Gulf War Oil Spill Its ecological effects and recovery rates of intertidal ecosystems at the Saudi Arabian Gulf coast - results of a 10-year monitoring period. Wissenschaftliche Arbeit im Rahmen des Habilitationsverfahrens im Fach Geographie an der Philosophischen Fakultät III der Universität Regensburg, 269 pp.

Bernier, P., Dalongeville, R., Dupuis, B., \& De Medwecki, V., 1995. Holocene shoreline variations in the Persian Gulf: example of the Umm al-Qowayn lagoon (UAE). Quaternary International 29, 95-103.

Bibby, T.G., 1973. Preliminary Survey in Eastern Saudi Arabia 1968. Copenhagen: Jutland Archaeological Society

Bosch, D., Bosch, E., 1989. Seashells of Southern Arabia. Dubai, UAE: Motivate Publishing. 
Bosch, D. T., Dance, S.P., Moolenbeek, R.G., Oliver, P.G., 1995. Seashells of Eastern Arabia. Dubai: Motivate Publishing.

Bou-Rabee, F., VanMarcke, E., 2001. Seismic vulnerability of Kuwait and other Arabian Gulf countries: information base and research needs. Soil Dynamics and Earthquake Engineering 21, 181-186

Bretzke, K., Armitage, S.J., Parker, A.G., Walkington, H., Uerpmann, H-P., 2013. The environmental context of Paleolithic settlement at FAY-NE1, Emirate Sharjah, UAE. Quaternary International, 300, 83-93.

Burkholder, G., 1972. Ubaid sites and pottery in Saudi Arabia. Archaeology, 25, 264-269.

Carter, R.A., Crawford, H.E., 2010. Maritime interactions in the Arabian Neolithic: evidence from H3, As-Sabiyah, an Ubaid-related site in Kuwait. Brill.

Claassen, C. 1998. Shells. Cambridge Manuals in Archaeology. Cambridge: Cambridge University Press.

Dearing, J., 1999. Magnetic susceptibility. Environmental magnetism: A practical guide, 6, pp.35-62.

Defense Mapping Agency, 1982. Topographic Map: Jubayl Al Barri 1:50,000.

Edition 3-DMD, Series K763, Sheet 5943, Washington, DC>

Doornkamp, J. C., Brunsden, D., Jones, D. K. C. 1980. Geology, geomorphology and pedology of Bahrain. Norwich, UK: Geobooks.

Drechsler, P., 2018, ed. Dosariyah: Reinvestigating a Neolithic Coastal Community on Eastern Arabia. British Foundation for the Study of Arabia Monographs No. 19, Archaeopress, pp.454. 
Duller, G.A.T., 2003. Distinguishing quartz and feldspar in single grain luminescence measurements. Radiation Measurements 37, 161-16

DuPont, C., Al Tamimi, A. G., 2008. Shells of the Qatari Shores. Second Edition. Doha: Ali Bin Ali Press.

El-Sabh, M.I., Murty, T.S., 1989. Storm surges in the Arabian Gulf. Natural Hazards 1, pp.371-385.

El-Sorogy, A., Youssef, M., Al-Kahtany, K., Al-Otaiby, N., 2016. Distribution of Intertidal Molluscs along Tarut Island Coast, Arabian Gulf, Saudi Arabia. Pakistan Journal of Zoology 48, 611-623,

Engel, M., Brückner, H., 2014. The South Qatar Survey Project (SQSP) Preliminary findings on Holocene coastal changes and geoarchaeological archives. Zeitschrift für Orient-Archäologie 7, 290-301.

Engel, M., May, S.M., Scheffers, A., Squire, P., Pint, A., Kelletat, D., Brückner, H., 2015. Prograded foredunes of Western Australia's macro-tidal coast implications for Holocene sea-level change and high-energy wave impacts. Earth Surface Processes and Landforms 40, 726-740.

Farrant, A.R., Ellison, R.A., Thomas, R.J., Pharaoh, T.C., Newell, A.J., Goodenough, K.M., Lee, J.R., Knox, R., 2012. The Geology and Geophysics of the United Arab Emirates. Volume 6, Geology of the western and central United Arab Emirates (Vol. 6). British Geological Survey.

Farrant, A.R., Duller, G.A., Parker, A.G., Roberts, H.M., Parton, A., Knox, R.W. and Bide, T., 2015. Developing a framework of Quaternary dune accumulation in the northern Rub'al-Khali, Arabia. Quaternary International 382, 132-144.

Felber, H., Hötzl, H., Maurin, V., Moser, H., Rauert, W., Zötl, J.G., 1978. Sea level 
fluctuations during the Quaternary period. In: Al-Sayari, S.S. \& Zötl, J.G. (eds.), Quaternary Period in Saudi Arabia. Springer, Wien, New York. p. 50-57.

Feulner, G.R., Hornby, R.J., 2006. Intertidal Molluscs in UAE Lagoons. Tribulus 18, 17-23.

Folk, R.L.,Ward, W.C., 1957. Brazos River bar: a study in the significance of grain size parameters. Journal of Sedimentary Research 27, 3-26

Fryberger, S.G., Al-Sari, A.M., Clisham, T.J., Rizvi, S.A.R., l-Hinai, K.G., 1984. Wind sedimentation in the Jafurah sand sea, Saudi Arabia. Sedimentology 31, 413-431.

Garzanti, E., Andò, S., Vezzoli, G., Dell'era, D., 2003. From rifted margins to foreland basins: investigating provenance and sediment dispersal across desert Arabia (Oman, UAE). Journal of Sedimentary Research 73, 572-588.

Glennie, K.W., 1970. Desert Sedimentary Environments. Elsevier, Amsterdam

Glennie, K W., 1998. The desert of southeast Arabia: A product of Quaternary climatic change. In, Alsharhan, A S, Glennie, K W, Whittle, G L, and Kendall, C G S C (Eds). Quaternary deserts and climate change. A.A.Balkema, Rotterdam, p. $279-291$

Goudie, A. S., 2007. Mega-Yardangs: A Global Analysis. Geography Compass 1, 6581.

Glover, E. A., Taylor, J.D., 2001. Systematic revision of Australian and Indo-Pacific Lucinidae (Mollusca: Bivalvia): Pillucina, Wallucina and descriptions of two new genera and four new species. Records of the Australian Museum 53, 263-292.

Glumac, B., Curran, H.A., Weigner, M.M., Motti, S. A., Pruss, S.B.,. 2012.

Distribution of oolitic sediment along a beach-to-offshore transect, Pigeon Cay, Cat Island, Bahamas: New insights into modern ooid formation. In, Proceedings of 
the 15th Symposium on the Geology of the Bahamas and other Carbonate Regions, pp. 69-79.

Groucutt, H.S., Grün, R., Zalmout, I.S., Drake, N.A., Armitage, S.J., Candy, I., ClarkWilson, R., Louys, J., Breeze, P.S., Duval, M., Buck, L.T., Kivell, T., Pomeroy, E., Stephens, N., Stock, J.T., Stewart, M., Price, G.J., Kinsley, L., Sung, W.W., Alsharek, A., Al-Omari, A., Zahir, M., Memesh, A.M., Al Murayyi, K.S.M., Zharani, B., Scerri, E.M.L., Petraglia, M.D., 2018. Homo sapiens in Arabia by 85,000 years ago. Nature Ecology and Evolution 2, 800-809.

Hadley, D.G., Brouwers, E.M., Bown, T.M., 1998. Quaternary paleodunes, Arabian Gulf coast, Abu Dhabi Emirate: age and palaeoenvironmental evolution. In: Alsharhan, A.S., Glennie, K.W., Whittle, G.L., Kendall, C.G.St.C. (Eds.), Quaternary Deserts and Climatic Change. A.A. Balkema, Rotterdam, pp. 123-139.

Hariri, M. M., 2014. Fractures system within Dammam Dome and its relationship to the doming process, Eastern Saudi Arabia. Arabian Journal of Geosciences 7, 4943-4956.

Hasan, A. K., 1994. A taxonomic review of the bivalve and gastropod mollusc fauna along the Saudi Intertidal Zone of the Arabian Gulf. Journal of King Abdulaziz University: Marine Sciences 7, 245-253.

Heiri, O., Lotter, A.F., Lemcke, G., 2001. Loss on ignition as a method for estimating organic and carbonate content in sediments: reproducibility and comparability of results. Journal of Paleolimnology 25, 101-110.

Horton, B.P., Edwards, R.J., Lloyd, J.M., 2000. Implications of a microfossil transfer function in Holocene sea level studies. In: Shennan, I. and Andrews, J., Editors, 2000. Holocene land-ocean interaction and environmental change around the North Sea. Geological Society, London. Special Publications 166, pp. 275-288. 
Hussain, M., 2006. Recognizing attributes and oomoldic porosity development in eolianite in an arid setting: An example from the Quaternary eolianite from the Arabian Gulf coastline, Saudi Arabia. Carbonates and Evaporites 21, 124-132

Huntings Geophysics Ltd. (1979). Report on mineral survey of the UAE, Al-Ain area, 9, p.29.

Jado, A.R., Zötl, J.G., 1984. Quaternary period in Saudi Arabia, vol 2:

Sedimentological, hydrogeological, hydrochemical, geomorphological, and climatological investigations in western Saudi Arabia. Wien, New York.

Jahangir, S., Siddiqui, G., Moazzam, M., Ayub, Z., 201 Clams of the families Tellinidae and Veneridae and blood cockle of family Arcidae from Phitti Creek and Sonmiani along the coast of Pakistan (Northern Arabian Sea). Pakistan Journal of Zoology 44, 259-266.

James, A.N., Little, A.L., 1994. Geotechnical aspects of sabkha at Jubail, Saudi Arabia. Quarterly Journal of Engineering Geology and Hydrogeology 27, 83-121.

Jordan, B.R., 2008. Tsunamis of the Arabian Peninsula a guide of historic events. Science of Tsunami Hazards 27, 31-46.

Kassler, P., 1973. The structural and geomorphic evolution of the Persian Gulf. In, Purser, B.H., ed. The Persian Gulf. Springer Berlin Heidelberg, pp.11-32.

Klasen, N., Engel, M., Brückner, H., Eichmann, R., Hausleiter, A., Intilia, A., alNajem, M.H., al-Said, S.F., 2011. Optically stimulated luminescence dating of the city wall system of Tayma (NW Saudi Arabia). Journal of Archaeological Science $38,1818-1826$.

Kohan, A., Badbardast. Z., Shokri, M., 2012. The Gastropod Fauna along the Bushehr Province Intertidal Zone of the Persian Gulf. Journal of the Persian Gulf (Marine Science) 3, 33-42 
Lambeck, K., 1996. Shoreline reconstructions for the Persian Gulf since the last glacial maximum. Earth and Planetary Science Letters 142, 43-57.

Larsen, C.E., 1983. Life and land use on the Bahrain Islands: the geoarchaeology of an ancient society. University of Chicago Press.

Lokier, S.W., Bateman, M.D., Larkin, N.R., Rye, P., Stewart, J.R., 2015. Late

Quaternary sea-level changes of the Persian Gulf. Quaternary Research 84, 69-81.

Lokier, S., Steuber, T., 2008. Quantification of carbonate-ramp sedimentation and progradation rates for the late Holocene Abu Dhabi shoreline. Journal of Sedimentary Research 78, 423-431.

Loughland, R. A., Al-Abdulkader, K. A., Wyllie, A., Burwell, B. O. 2012. Anthropogenic induced geomorphological change along the Western Arabian Gulf Coast. In, Piacentini, T. (Ed.), Studies on Environmental and Applied Geomorphology, InTech, Rijeka: pp, 191-218.

Mandaville, J.P., 1990. Flora of Eastern Saudi Arabia. London. 482 pp.

Masry, A.H., 1974. Prehistory in Northeastern Arabia. Coconut Grove.

McClure, H.A., Al-Shaikh, N.Y., 1993. Palaeogeography of an 'Ubaid archaeological site, Saudi Arabia. Arabian Archaeology and Epigraphy 4, 107-125.

McClure, H.A., Vita-Finzi, C., 1982. Holocene shorelines and tectonic movements in eastern Saudi Arabia. Tectonophysics 85, 37-T43.

Munro, R.N., Walkington, H., Franks, S., Wilkinson, T.J., Sanderson, D.C.W., 2013. Aspects of late Cainozoic aeolian landscapes in Arabia: implications for early Man. In: Al-Ansary, A.R., Al-Muaikel, K.I. and Alsharekh, A.M. (eds.) Man and Environment in the Arab World in Light of Archaeological Discoveries. Abdul Rahman Al-Sudairy Foundation: Al-Jouf, Saudi Arabia, pp. 7-46. 
Murray, A.S., Olley, J.M., 2002. Precision and accuracy in the optically stimulated luminescence dating of sedimentary quartz: a status review. Geochronometria 21, $1-16$.

Murray, A.S., Wintle A.G. 2000. Luminescence dating of quartz using an improved single-aliquot regenerative-dose protocol. Radiation Measurements 32, 57-73.

Murray, A.S., Wintle, A.G. 2003. The single-aliquot regenerative-dose protocol: potential for improvements in reliability. Radiation Measurements 37, 377-381.

Nasir, S., Al-Sayigh, A.R., Safarjalani, A., 2007. Sedimentology of the lower Hofuf Formation, Eastern Province of Saudi Arabia, and the chances for gold prospection. Neues Jahrbuch für Geologie und Paläontologie-Abhandlungen 243, 325-342.

Oliver, P. G., 1992. Bivalved Seashells of the Red Sea. Cardiff: The National Museum of Wales.

Parker, A.G., Preston, G.W., Parton, A., Walkington, H., Jardine, P.E., Leng, M.J., Hodson, M.J., 2016. Low-latitude Holocene hydroclimate derived from lake sediment flux and geochemistry. Journal of Quaternary Science 31, 286-299.

Parker, A.G., Morley, M.W., Parton A., Preston, G.W, Russ, H., Armitage, S.J., 2018. Ch 2, Geomorphology, Geoarchaeology and Palaeoenvironments. In, Drechsler, P. (ed.). Dosariyah: Reinvestigating a Neolithic coastal community in the eastern Arabia. British Foundation for the Study of Arabia Monograph No.19. Archaeopress: Oxford, pp. 21-55.

Pedoja, K., Husson, L., Regard, V., Cobbold, P.R., Ostanciaux, E., Johnson, M.E., Kershaw, S., Saillard, M., Martinod, J., Furgerot, L., Weill, P., 2011. Relative sealevel fall since the last interglacial stage: Are coasts uplifting worldwide? EarthScience Reviews 108, 1-15. 
Petraglia, M.D., Alsharekh, A., Breeze, P., Clarkson, C., Crassard, R., Drake, N.A., Groucutt, H.S., Jennings, R., Parker, A.G., Parton, A., Roberts, R.G., 2012. Hominin dispersal into the Nefud desert and Middle Palaeolithic settlement along the Jubbah palaeolake, northern Arabia. PLoS One 7, p.e49840.

Prescott, J.R. and Hutton, J.T. (1988) Cosmic ray and gamma ray dosimetry for TL and ESR. Nuclear Tracks and Radiation Measurements 14, 223-227.

Preston, G.W., Thomas, D.S., Goudie, A.S., Atkinson, O.A., Leng, M.J., Hodson, M.J., Walkington, H., Charpentier, V., Méry, S., Borgi, F., Parker, A.G., 2015. A multiproxy analysis of the Holocene humid phase from the United Arab Emirates and its implications for southeast Arabia's Neolithic populations. Quaternary International 382, 277-292.

Puls, D.D., Jameson, J., Al Manai, A., 2008. Changing Paradigms: A Stratigraphic Record from and Carbonate-Clastic Incised Valley Fill Formed During Holocene Sea Level Rise, Doha, Qatar. European Association of Geoscientists \& Engineers Conference Proceedings GEO 2008, Article 90077, cp246-00293

Rakha, K, Al-Salem, K., Neelamani, S., 2007. Hydrodynamic Atlas for the Arabian Gulf. Journal of Coastal Research 50, 550-554.

Reinink-Smith, L.M., 2015. AMS-dated mollusks in beach ridges and berms document Holocene sea-level and coastal changes in northeastern Kuwait Bay. Quaternary Research 84, 200-213.

Ridley, A.P., Seeley, M.W., 1979. Evidence for recent coastal uplift near Al Jubail, Saudi Arabia. Tectonophysics 52, 319-327.

Saner, S., Al-Hinai, K., Perincek, D. (2005). Surface expressions of the Ghawar structure, Saudi Arabia. Marine and Petroleum Geology 22, 657-670. 
Schulz, E., Whitney, J.W., 1986. Upper Pleistocene and Holocene lakes in the An Nafud, Saudi Arabia. Hydrobiologia 143,175-190

Shennan, I., Peltier, W.R., Drummond R., Horton, B., 2002. Global to local scale parameters determining relative sea-level changes and the post-glacial isostatic adjustment of Great Britain. Quaternary Science Reviews 21, 397-408

Shennan, I., Bradley, S., Milne, G., Brooks, A., Bassett S., Hamilton. S., 2006.

Relative sea-level changes, glacial isostatic modelling and ice-sheet reconstructions from the British Isles since the Last Glacial Maximum. Journal of Quaternary Science 21, 585-599

Sheppard, C., Price, A., Roberts, C., 1992. Marine ecology of the Arabian region. Academic Press, London, 360 pp.

Stevens, T., Jestico, M., Evans, G., Kirkham, A., 2014. Eustatic control of late Quaternary sea-level change in the Arabian/Persian Gulf. Quaternary Research $82,175-184$.

Teller, J.T., Glennie, K.W., Lancaster, N., Singhvi, A.K., 2000. Calcareous dunes of the United Arab Emirates and Noah's Flood: the postglacial reflooding of the Persian (Arabian) Gulf. Quaternary International 68-71, 297-308.

Thoppil, P.G., Hogan, P.J., 2010. Persian Gulf response to a wintertime shamal wind event. Deep Sea Research Part I: Oceanographic Research Papers 57, 946955.

Tooley, M.J., 1978. Sea-level changes. North-West England during the Flandrian Stage. Clarendon Press, Oxford

Uchupi, E., Swift, S.A., Ross, D.A., 1996. Gas venting and late Quaternary sedimentation in the Persian (Arabian) Gulf. Marine Geology 129, 237-269. 
Van de Velde, T., De Vrieze, M., Surmont, P., Bodé, S., Drechsler, P., 2015. A geochemical study on the bitumen from Dosariyah (Saudi-Arabia): tracking Neolithic-period bitumen in the Persian Gulf. Journal of Archaeological Science $57,248-256$.

Vincent, P., 2008. Saudi Arabia: an Environmental Overview. Taylor \& Francis: London, 309 pp.

Willan, R. C., 1993. Taxonomic revision of the family Psammobiidae (Bivalvia: Tellinoidea) in the Australian and New Zealand region. Records of the Australian Museum. Supplement 18, 1-132.

Williams, A.H., Walkden, G.M., 2002. Late Quaternary highstand deposits of the southern Arabian Gulf. In: Modern and Ancient Carbonate Eolianites. Sedimentology, Sequence Stratigraphy and Diagenesis. Eds. F.E. Abegg, P.M. Harris and D.B Loope. Society of Mineralogists and Paleontologists Special Publication 712, 77-92. 